\title{
برنامج تدريبي للوالدين لتنمية بعض مفاهيم طفل الروضة من خلال الألعاب التربوية
}

|عداد

الباحثة / هبة صلاح الشناوي'

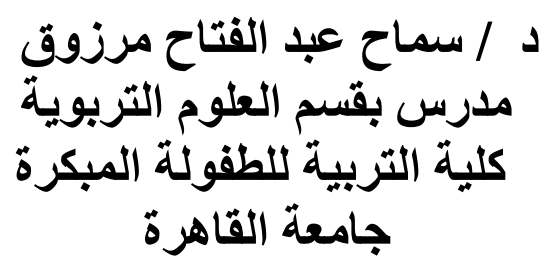

\section{إثراف}

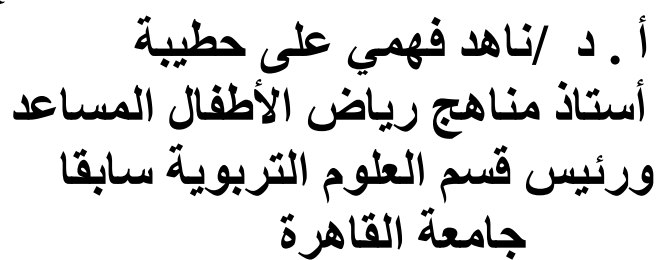

مقدمة:

تعتبر مرحلة الطفولة من أهم المراحل في تكوين شخصية الفرد فهي النواة الأساسية لنمو الشخصبة بما تحمله من مفاهيم وقيم وسلوكيات.

ولأهمية هذة المرحلة فيجب الإهتمام بمن يساهم في تشكيل شخصية الطفل في هذه المرحلة فالأسرة لها دور مهم في تشكيل شخصية الطفل فهي تعتبر العالم الأول الذى يستقبل الطفل، ولذا يجب أن يهتم الوالدان بلعب الطفل و ألعابه التعليمية التي تنمي لديه المفاهيم و المهار ات المختلفة فمن خلال البيئة المحيطة بالطفل يمكن إنتاج ألعاب تعليمية مختلفة تساعد على نموه وتطوره. و لا ننسى دور الو الدين فى التخطيط و الإشراف على الألعاب التربوية، فالو الدان لهم دور هام فى نجاح العملية التعليمية للطفل وهو فهم ومساندة جهود المعلمة فى الروضة ولكي يتم هذا النجاح فلابد من مشاركة الو الدين للمعلمات في تعليم الطفل لما له أثر كبير في نمو الطفل من الناحية الاجتماعية و العاطفية

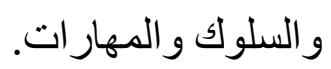

وتثير هدى الناشف أن تعاون أولياء الأمور فى تربية أطفالهم وتو عيتهم بحاجات أطفالهم وتدريبهم على أساليب التربية الناجحة هي التي تحقق النمو الثامل وتمنح الأطفال فرصا متكافئة للتقدم والنمو وقد نظمت لهذا الغرض برامج داخل البيوت مع الأسر التي لديها أطفال دون سن التعليم الإلزامى ويطلق

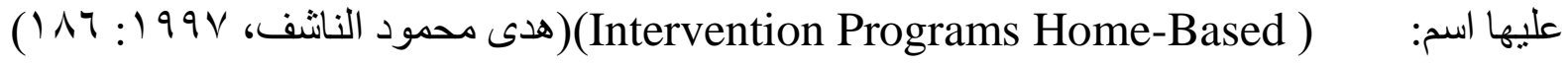


وركزت بعض الدراسـات و البحوث على أهميـة البر امج التدريبيـة وورش العمل الخاصـة بالأبـاء وكانت نتائجها جيدة ومن هذه الدراسـات: دراسـة "حنان أبو المعارف وتوصلت نتائجها إلى عمل دليل

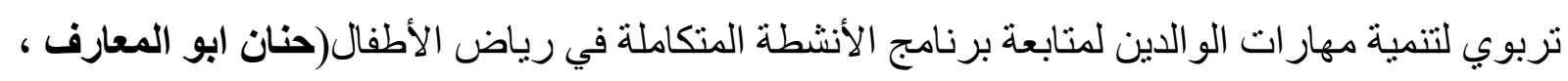
( $($ r. . T وورشة العمل التي قامت بتتفيذها سيزور للو الدين و التي تهدف إلى: رفع كفاءة الو الدين وتزويدهم

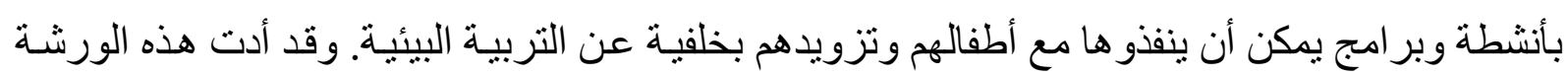

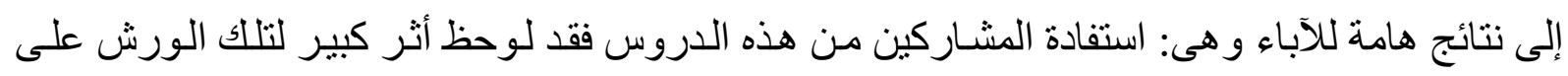

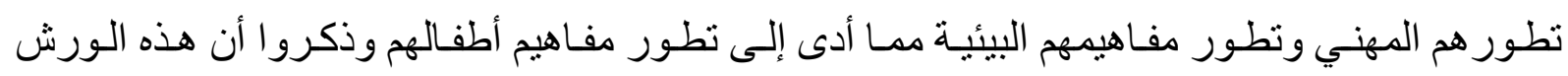
أعطتهم الكثير من السعادة والمر ح و الأفكار البسيطة المثتعة (Sisor, D., 2001 ). وتوصى "ليلى كرم الدين" بأنه ينبغي أن ينظر إلى ديناميكية تفاعل البر امج التثقيفية مع الو الدين من

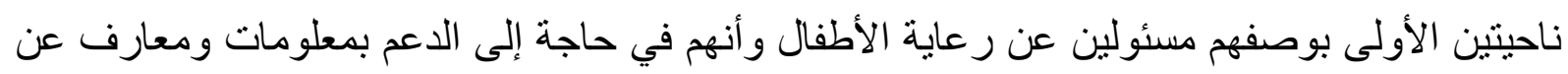

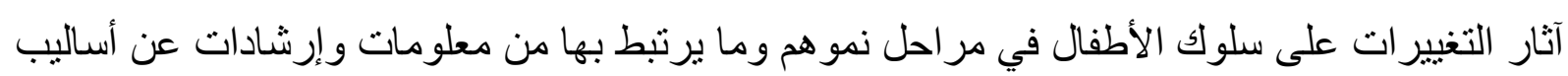

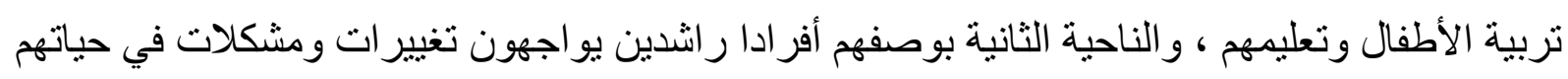

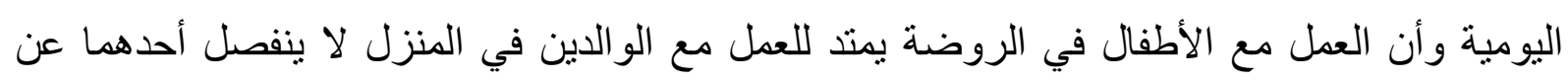

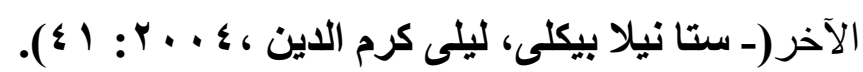

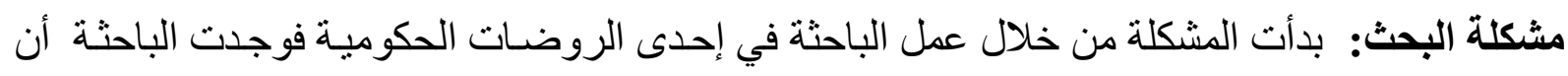

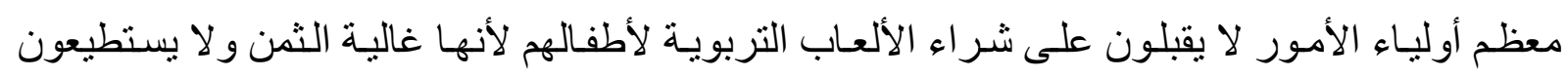

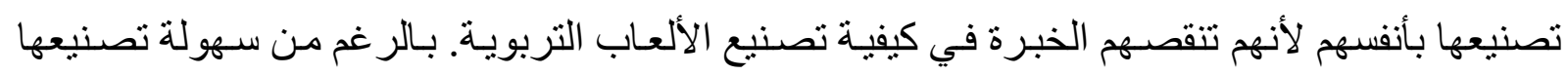

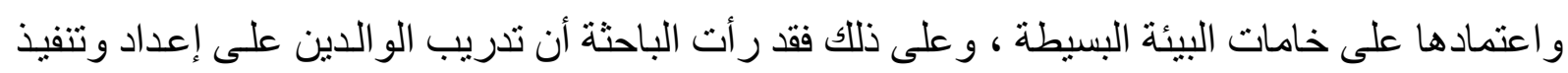
تلك الألعاب التربوية يمكن أن تساهم في حل المشكلة ولذلك تقوم الباحثة بعمل برنامج تدريبي للو الدين

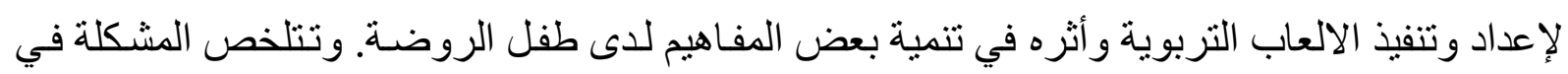

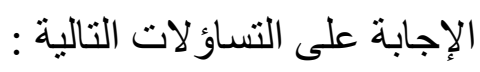

1 - ما البرنامج التدريبى الدقدم للو الدين في إعداد الالعاب التربوية من خامات البيئة لدى طفل

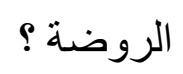

r- ما فاعلية البرنامج التدريبي المقدم للو الدين في تنمية بعض المفاهيم لطفل الروضة؟ 


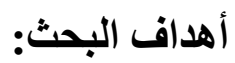

ا ـ الوقوف على أهمية الألعاب التربوية في تتمية بعض المفاهيم لدى طفل الروضة.

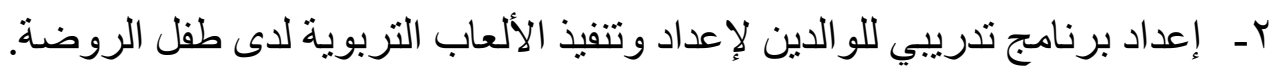

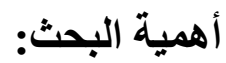

* المساهمة في مجال الدراسة للارتقاء بالو الدين في إعداد وتنفيذ الألعاب التربوية لاى طفل الروضة

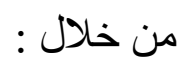

أ- بناء برنامج تدريبي للو الدين لإعداد وتتفيذ الألعاب التربوية لاى طفل الروضة .

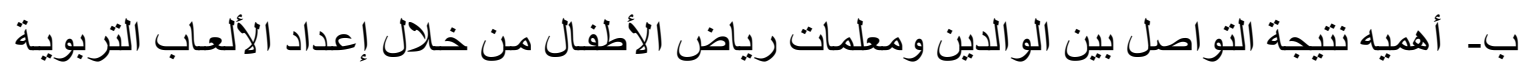
في تنمية بعض الدفاهيم لدى طفل الروضة.

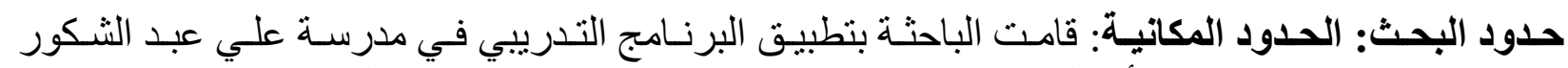

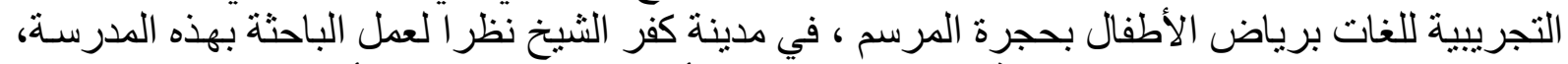

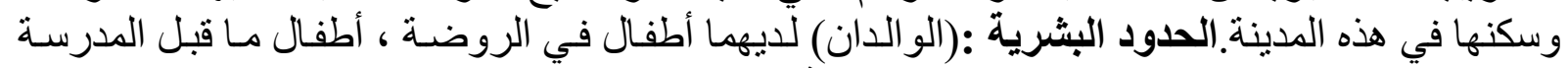

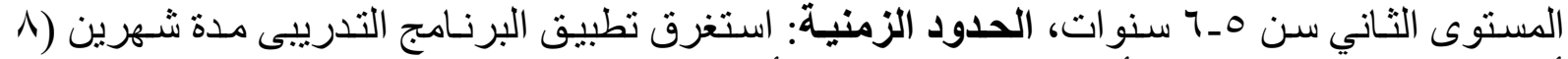

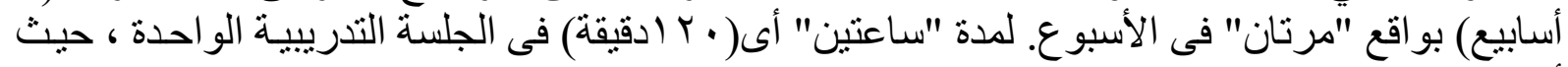

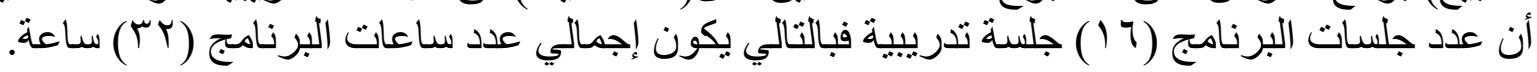

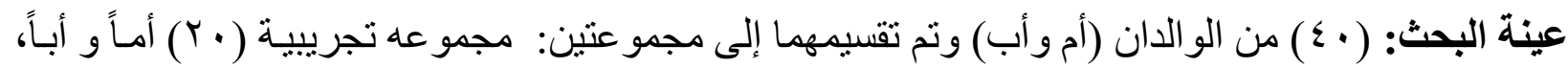

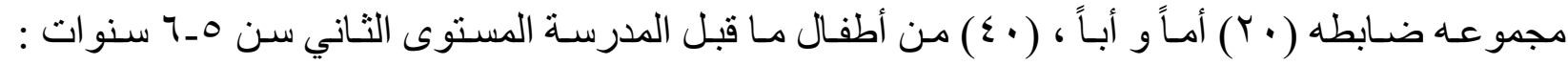

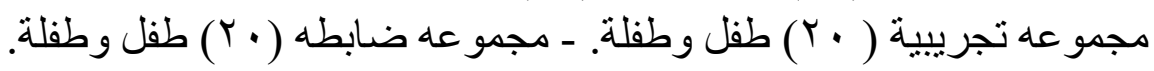

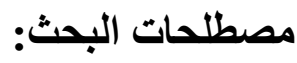

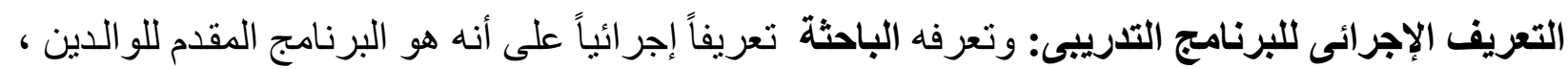

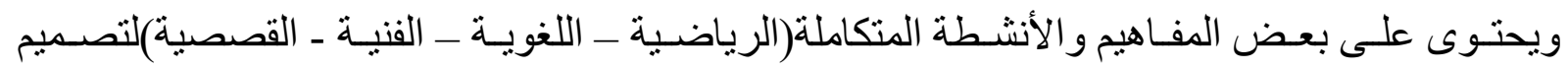

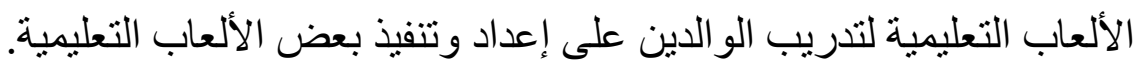

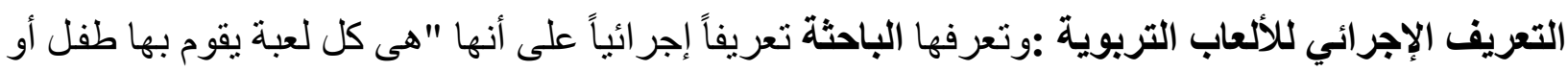

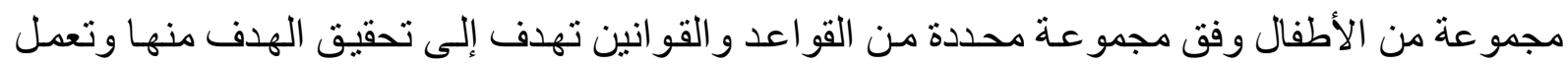
على تتمية بعض المفاهيم و المهار ات المخت المختلة لدى طفل الروضة".

الإطار النظري للبحث:

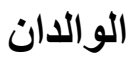

الأسرة تعتبر أول مؤسسة يتعامل معها الطفل من مؤسسات المجتمع، وهى البيئة الثقافية التى يكتسب منها الطفل لغته وقيمه، وتؤثر فى تكوينه الجسمى والنفسى والاجتماعى و العقائدى، فالأسرة

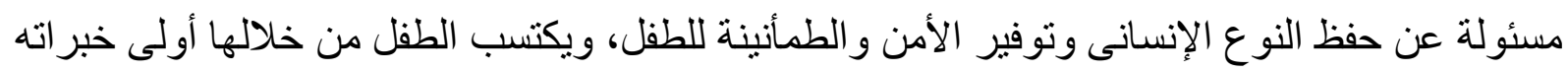
الصوتيه ويدرك وجود علاقة جسمية بين مايسمعه من أصوات مختلفة وبين الظروف و المواقف فى البيئة 
التى يعيش فيها. و ودور الأسرة فى التربية بصفة عامة وفى تربية طفل ماقبل الددرسة بصفة خاصة لا

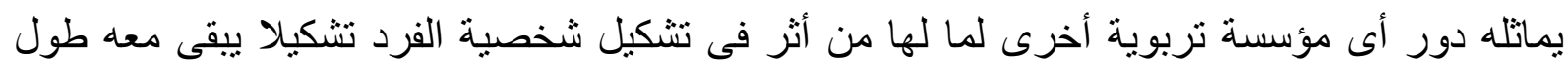

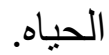

التعاون بين الوالدين ومعلمات رياض الأطفال علاقه الو الدين بالروضة مهمة جدا و هذه العلاقة تتجسد في الإدي

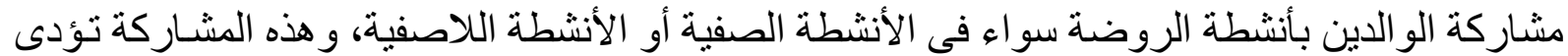

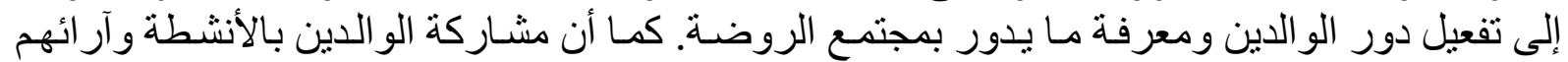

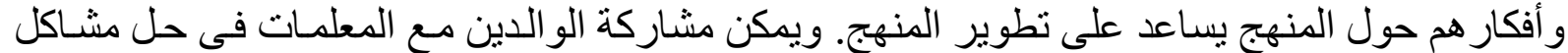

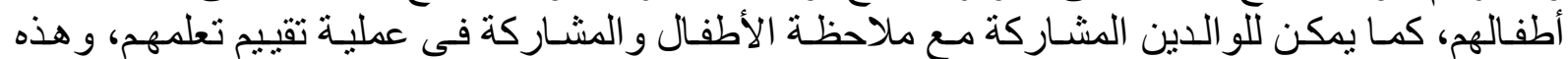

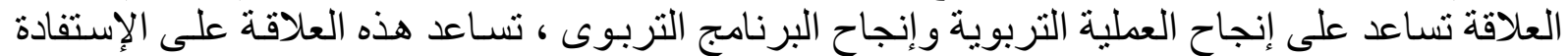

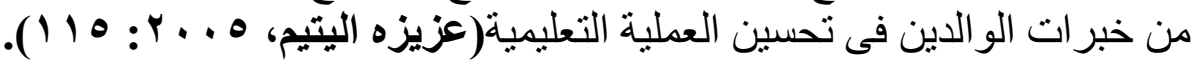

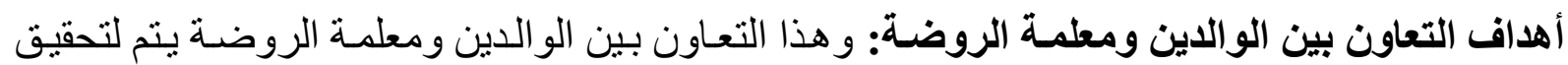

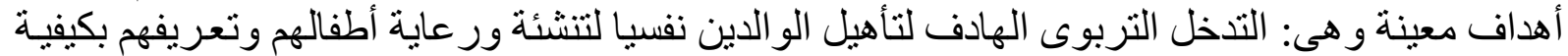

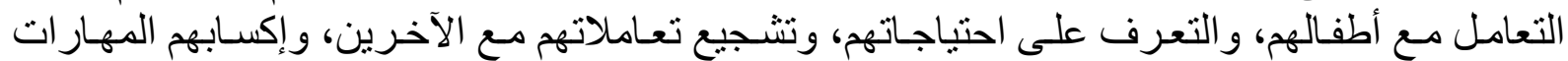

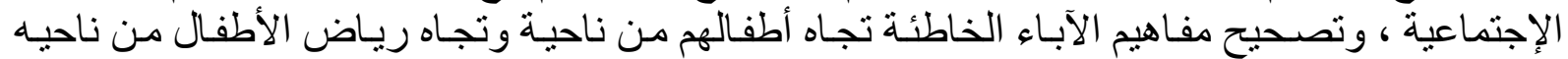

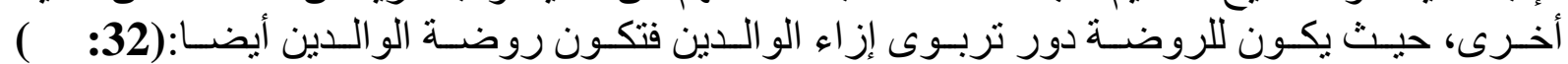

Farrenkopf, Crol, and others, 1995)

* التتبؤ بإنجاز ات وكفاءة الأطفال الممهدة للار اسة الأكاديمية فقى دراسة عن تحليل المتغيرات الثخصية و الإجتماعية كمؤشرات للكفاءة الممهدة للدر اسة الأكاديمية لأطفال ما قبل المدرسة. إلا أن تفاعل الو الدين

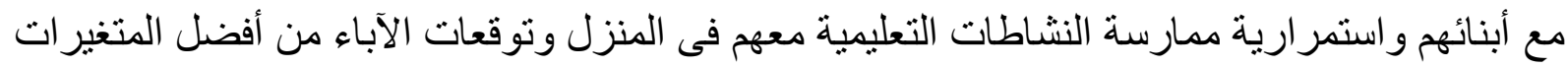
Mantzicopoulos,- panayota- y, المنبئة بإنجاز ات الأطفال والكفاءة الممهدة للار اسة الأكاديمية

\section{and others( 1993):64)} *نمو السلوك التكيفى للطفل وترى (Kenneth and others) أن التعاون بين البيت والروضة أمر ضرورى للإلمام بأهم المهارات الإجتماعية التى اكتسبها الطفل فى محيط أسرته وتأثثيرها على تكيفه الاجتماعى فى الروضة، ومعرفة كيفية التعامل معه إزاء المو اقف المختلفة فى الروضة وبالتالى تؤدى

Kenneth Rubin - : 420 مساهمة الأسرة، وتعاونها مع الروضة إلى نمو السلوك التكيفى للطفل

(Mills Rose Mary (1990

أساليب الاتصال بين الوالدين ومعلمة الروضة

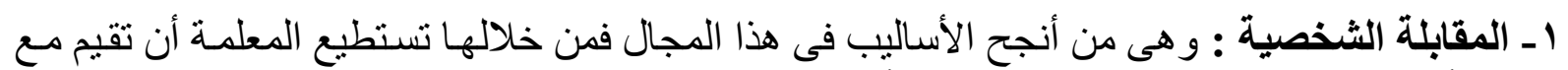

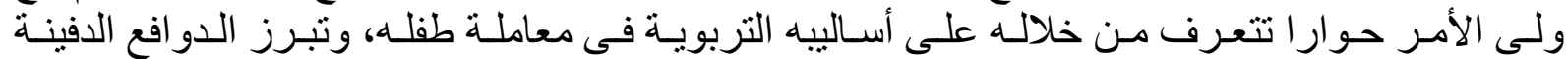

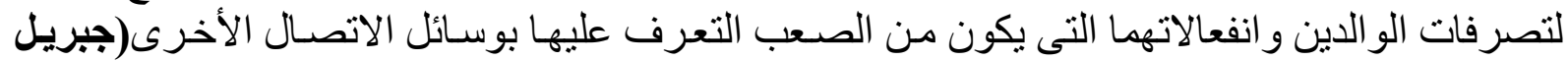

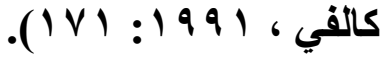

r ـ ندوات الو الدين: وتهدف ندو ات الو الدين إلى بناء علاقة وثيقة معهما، وكسب ثقتهما و التعاون معهما لتحقيق أهداف الروضة التربوية، و على الدديرة أن تعد جداول أولياء الأمور لكناقتنات مفتوحة وتختار 


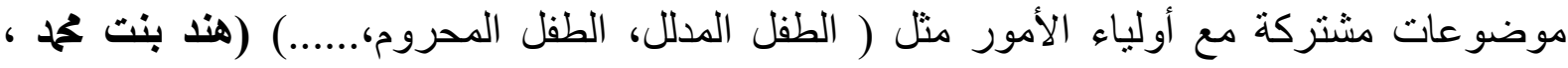
. (qr: $r \ldots$ rـ الزيارات المنزلية: وتقوم فيها المعلمة بتحديد وقت مع الو الدين لزيارة الطفل فى منزله وهذا يعطى

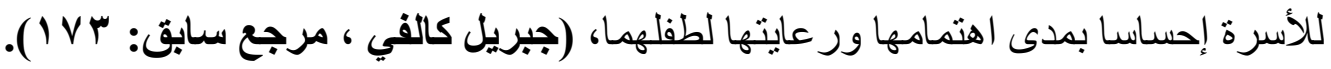
ـ ـ المحادثات التليفونيه: وتتم هذه الدحادثات بين معلمات الروضة و الو الدين وتهدف إلى الدحافظة على تواصل العلاقه بينهما، وتعرف طبيعة البيئة التى يعيش فيها.

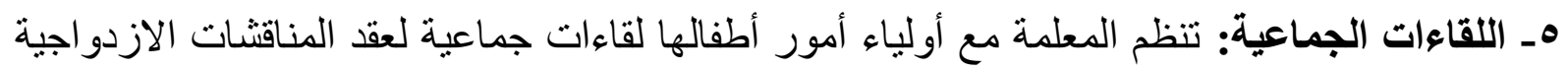

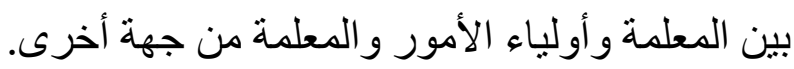

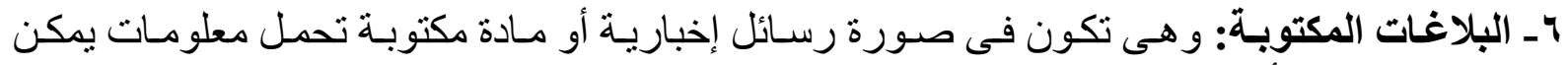

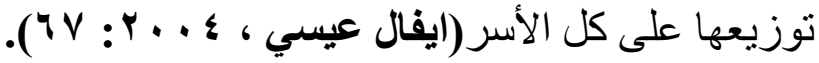

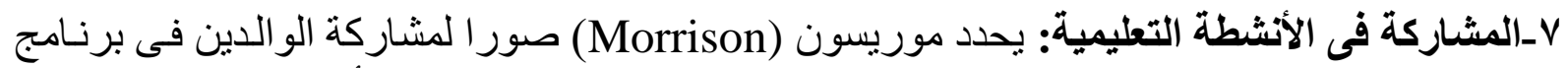

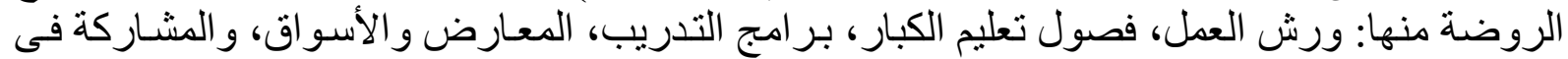
الأنشطة التعليمية داخل حجرة العمل:Morrison. S., (1990): 421)

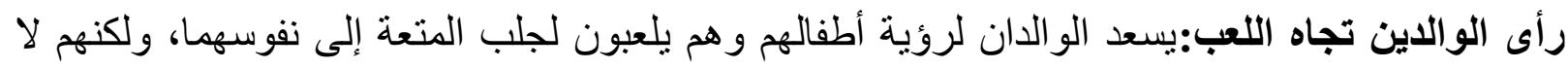

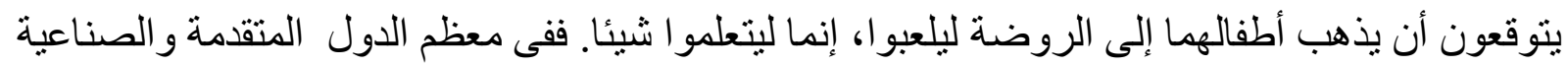
يسعى الو الدان إلى شغل وقت الفراغ لدى أطفالهما، وفى كثير من الدول مثل أمريكا و اليابان و الصين

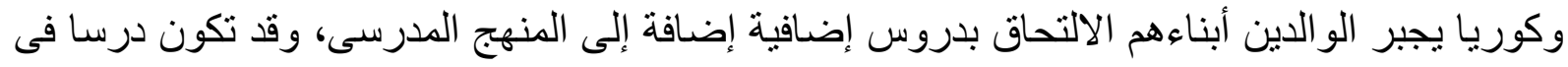

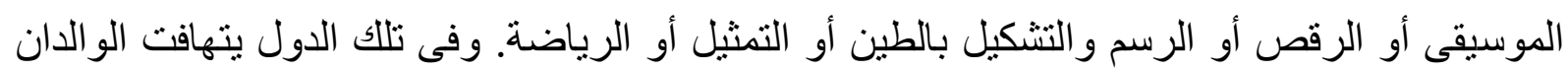

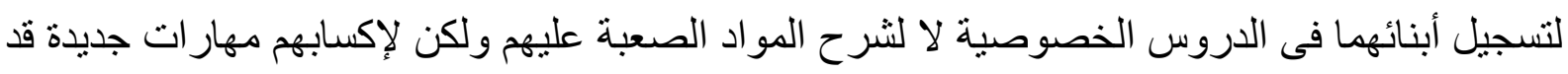
لا تعطى لهم فى الددارس، وإذا كانت هذه النظرة من الآباء لتقوية المعلومات لاى أبنائهم وزيادة

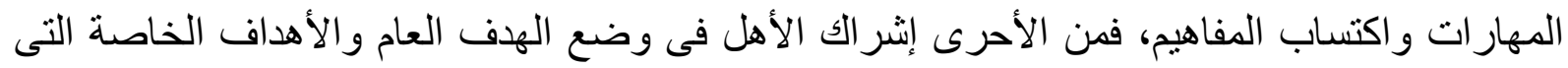

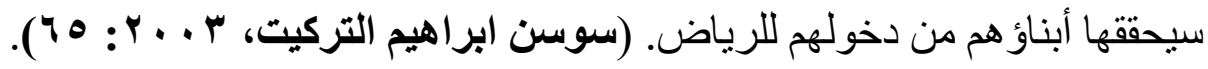

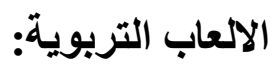
ويعر فها عبدالله خطابية بأنها نثاط موجه يقوم به الأطفال لتنمية سلوكهم وقدر اتهم العقلية و الجسمية

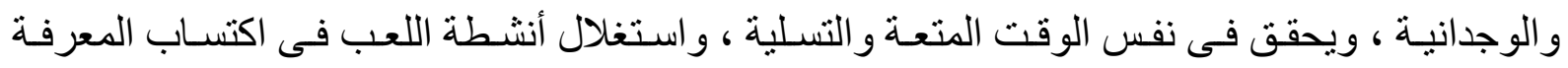

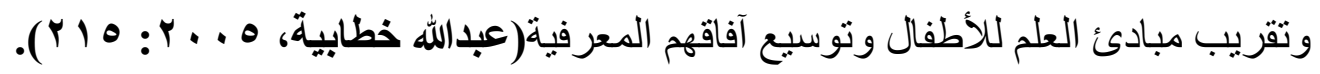
أما حنان العنانى فتعرفها على أنها كل لعب يهدف إلى تحقيق غرض خلى خاص ويكون منه تنمية مو اهب وقابليات الطفل وتوسيع آفاق معرفته بصورة عامة ومساعدنه على استيعاب مواد البرنامج التعليمى

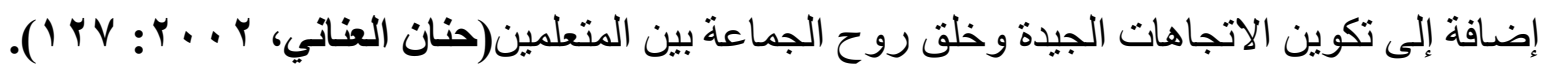


تصميم الألعاب التربوية وشروط اللعبة الجيدة : هناك شروط يجب أن تكون منو افرة فى اللعبة التى يكون الفرد بصدد تصميمها حتى نطلق عليها اسم لعبة تربوية:

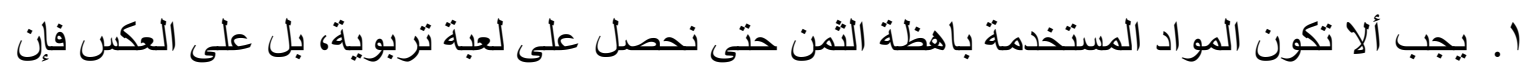

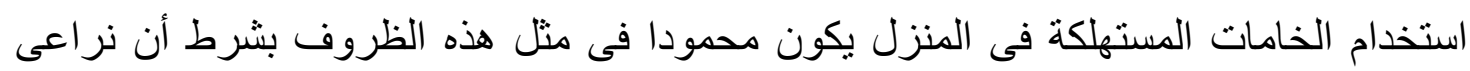

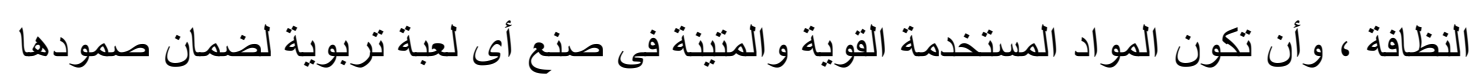
و واستخدامها أكثر من مرة فى اللعب. r. إنر الك الطفل فى التصميم و التخطيط لعمل لعبة و عمل تجارب على اللعبة قبل البدء باللعب بها

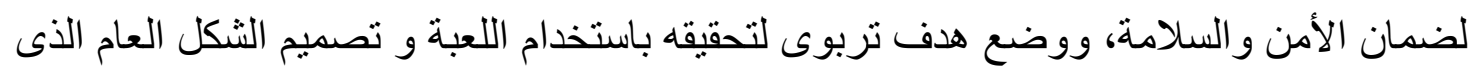

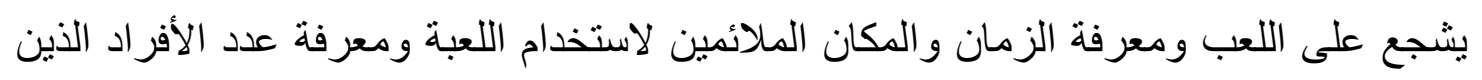

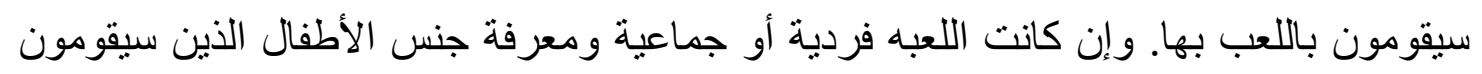

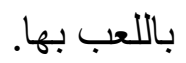
r. . يجب أن تكون إجر اءات تصميم اللعبة وتتفيذها سهلة وغير معقدة ولا تحتوى على تفاصيل معقدة

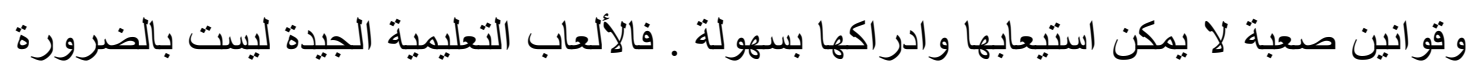
كثيرة التفاصيل وكثيرة التعقيد ، أن تكون سهلة الاستخدام و غير ضارة بصده انده الطفل و ألوانها

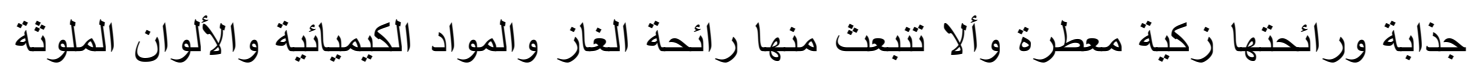

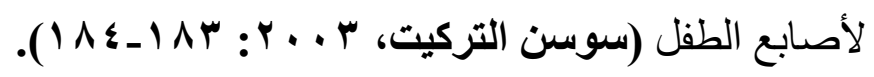

مراحل إستخدام الألعاب التربوية: إن الإستخدام الفعال للألعاب التربوية يمر بعدة مر احل وقد اتفق أحمد النجدى وآخرون ، محمد الحيلة على المر احل الآتية:

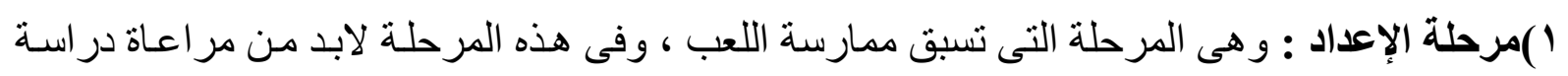

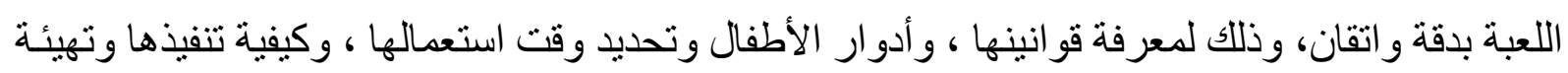

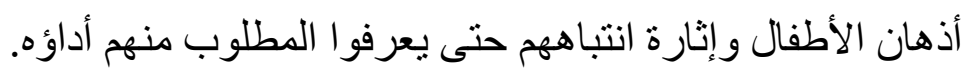

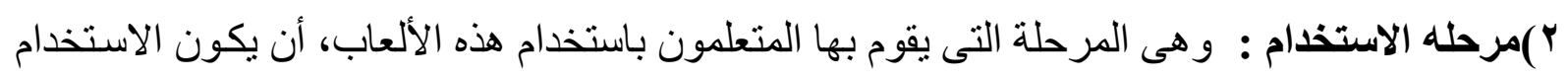
هادفا بمعنى أن يحقق الطفل ما نتوقع منها، عدم المقارنة بين الاطفال وبعضئها.

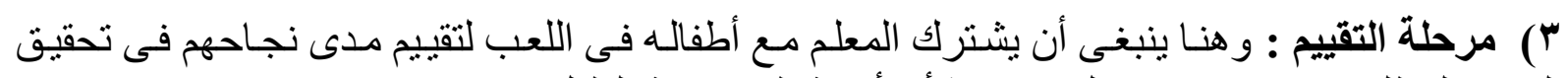

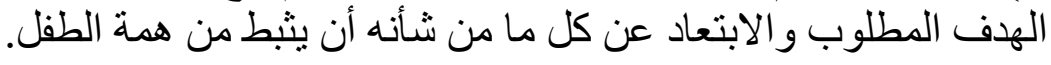

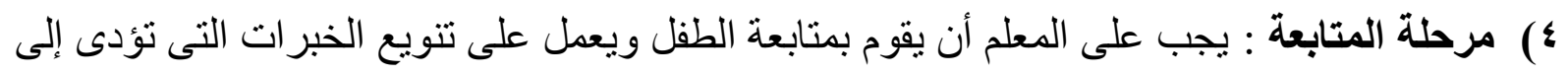

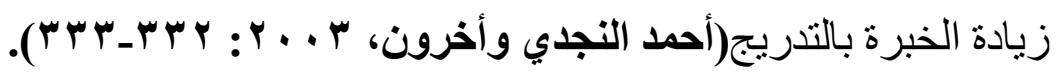

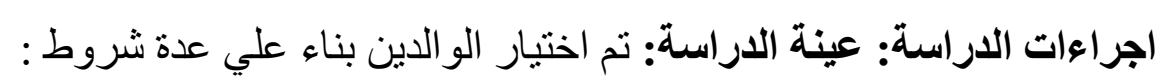


أن يكون لديهم الاستعداد للمشاركة في البرنامج التدريبي وفق استمارة استطلاع الرأي للوالدين، أن

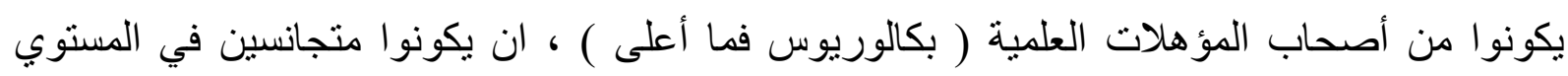

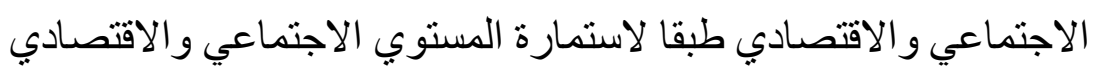

بالنسبة لمجموعة الأطفال تم اختيارهم بناء علي عدة شروط :أن تتراوح أعمار هم ما بين (

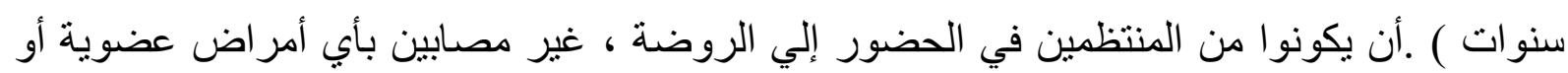
عصبية وذلك من خلال الاطلاع علي ملفات الأطفال في الروضة وسؤ ال المعلمات و الأخصائيات . كما هو موضح بالجدول الآتي: جدول( ) توزيع العينة في المجموعة التجريبية والمجموعة الضابطة

\begin{tabular}{|c|c|c|}
\hline المجموعة الضابطة (ن= +r) & 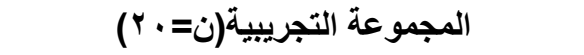 & المجموعات \\
\hline لا تنلقى أي برامج & تتلقى برنامج الو الدين لإعداد الألعاب التربوية & عينة الو الدين (ن= · ؛) \\
\hline لا تتلقى أي تدريب جديد & يتم ملاحظة انتقال أثر تدريب الو الدين عليهم & عينة الأطفال (ن= ؛ ؛) \\
\hline
\end{tabular}

التجانس بين مجموعات الدراسة: وتم تحقيق التجانس بين أفراد المجموعنين في كل من العمر الزمني

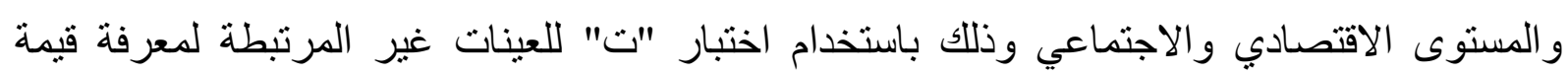

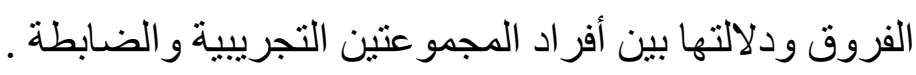
بالنسبة للعمر الزمني والمستوي الاجتماعي والاقتصادي : جدول (ץ) قيمة (ت) ودلالتها للفروق بين منوسطي درجات أفر اد المجمو عتين التجريبية و الضابطة في العمر الزمني و المستوى الاجتماعي و الاقتصادي

\begin{tabular}{|c|c|c|c|c|c|c|c|c|}
\hline |الدلالة & قيمة (ت) & الحرجية & $\varepsilon$ & p & ن & |لقياس & & |الاختبار \\
\hline \multirow{2}{*}{ غيردالة } & \multirow{2}{*}{.$\vee V q V$} & \multirow{2}{*}{$r \wedge$} & 9.0400 & $0 . r$. & $r$. & تجريبية & \multirow{2}{*}{ الوالدان } & \multirow{4}{*}{$\begin{array}{l}\overline{3} \\
\overline{3} \\
. \overline{3}\end{array}$} \\
\hline & & & ร.ภรVA & 0.0. & $r$. & ضابطة & & \\
\hline \multirow{2}{*}{ غيردالة } & \multirow{2}{*}{ צ 1.9} & \multirow{2}{*}{$r \Lambda$} & 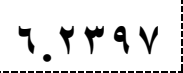 & $\leqslant 1.7$ & r. & تجرييية & \multirow{2}{*}{ الأطقال } & \\
\hline & & & $v .0 q, r$ & $\leqslant \mu .0$. & r. & |ضابطة & & \\
\hline \multirow{2}{*}{ غيردالة } & \multirow{2}{*}{1.599} & \multirow{2}{*}{ r } & $5 . \cdot 111$ & YT.T. & r. & تجريبية & \multirow{2}{*}{ الوالدان } & \multirow{4}{*}{ 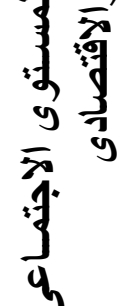 } \\
\hline & & & r.tor. & r^. $\vee$. & $r$. & ضابطة & & \\
\hline \multirow{2}{*}{ غيردالة } & \multirow{2}{*}{ Y..01 } & \multirow{2}{*}{ r } & $\varepsilon . .1$ ro & rv.q. & r. & تجرييية & \multirow{2}{*}{ الأطفال } & \\
\hline & & & 0.19 .1 & Yq.०. & r. & |ضابطة & & \\
\hline
\end{tabular}


يتضح من الجدول السابق تكافؤ مجموعات الدراسة (الوالدين ـ الأطفال) في العمر الزمني و المستوي الاجتماعي و الاقتصادي لعدم وصول قيمة "ت" لحد الدلالة المقبولة إحصائيا . - بالنسبة إلي اختبار المفاهيم للوالدين :

جدول (r) قيمة (ت) ودلالتها للفروق بين منوسطي درجات أفراد المجموعتين التجرييية و الضابطة في اختبار الدفاهيم للوالدين .

\begin{tabular}{|c|c|c|c|c|c|c|c|c|}
\hline مسلتـتوى & "قيمــــــة & د.د & 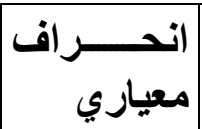 & | متوسط & ن & المجموعة & \multicolumn{2}{|c|}{ اختبار المفاهيم } \\
\hline \multirow{2}{*}{ غير دالة } & \multirow{2}{*}{$1.19 \leq-$} & \multirow{2}{*}{ r } & $1.1 \leqslant V 1$ & $7.0 \ldots$ & $r$. & التجريبية & \multirow{2}{*}{ المفاهيم الرياضية } & \\
\hline & & & $1 . K r \leq \varepsilon$ & $7.90 \ldots$ & $r \cdot$ & الضابطة & & \\
\hline \multirow{2}{*}{ غير دالة } & \multirow{2}{*}{$\because r r q$} & \multirow{2}{*}{ rᄉ } & D & $7.10 \ldots$ & $r \cdot$ & التجريبية & \multirow{2}{*}{ المفاهيم اللغوية } & \\
\hline & & & 1.5 .97 & $7 . \vee 0 \ldots$ & $r$. & الضابطة & & \\
\hline \multirow{2}{*}{ غير دالة } & \multirow{2}{*}{$\because 1 r \cdot-$} & \multirow{2}{*}{ rᄉ } & $1.54 . V$ & $7 . v \ldots$ & $r$. & التجريبية & \multirow{2}{*}{ المفاهيم الفنية } & \\
\hline & & & I.rVIV & $7 . \vee 0 \ldots$ & $r \cdot$ & الضابطة & & \\
\hline \multirow{2}{*}{ غير دالة } & \multirow{2}{*}{.$\Delta \wedge r$} & \multirow{2}{*}{$\mu \wedge$} & $1 . r r \leq \varepsilon$ & $v_{.} .0 \ldots$ & $r \cdot$ & التجريبية & \multirow{2}{*}{ 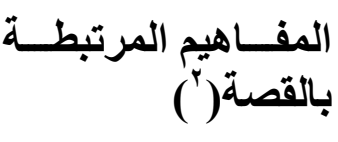 } & \\
\hline & & & $1 . \leqslant V Y T$ & $\checkmark . \wedge \ldots$ & $r \cdot$ & الضابطة & & \\
\hline \multirow{2}{*}{ غير دالة } & \multirow{2}{*}{$\because r \wedge r_{-}$} & \multirow{2}{*}{$r \wedge$} & $1 . r 9 r v$ & $r v_{.} 1 \ldots$ & $r \cdot$ & التجريبية & \multirow{2}{*}{ المجموع } & \\
\hline & & & $1.997 \mathrm{~V}$ & YV.YOA & $r$. & الضابطة & & \\
\hline
\end{tabular}

يتضح من الجدول السابق عدم وجود فروق دالة إحصائياً بين متوسطي درجات المجمو عتين

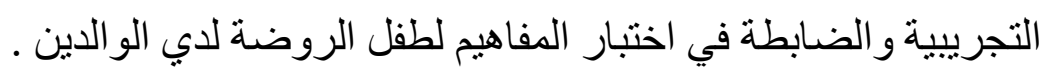
أدوات البحث: استمارة المستوي الاقتصادي والاجتماعي إعداد عبد العزيز الثخص (• • • ب)، اختبار

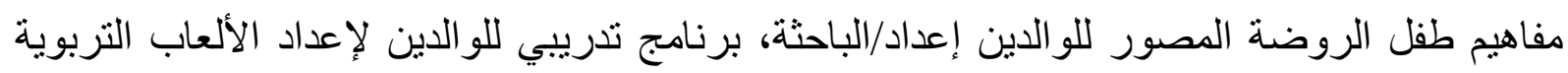

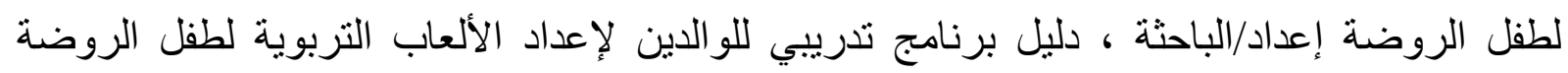
إعداد/الباحثة.

الأداه الأولي :مقياس المستوى الاقتصادي والاجتماعي للأسرة: أعد هذا المقياس عبد العزيز الثخص

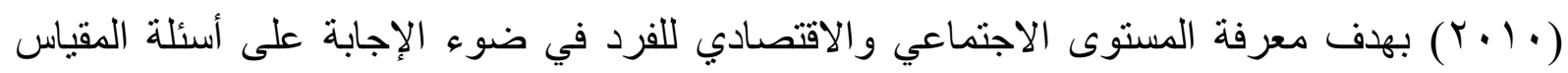

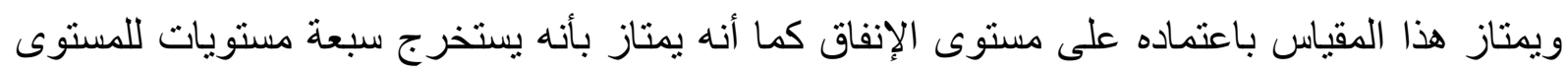

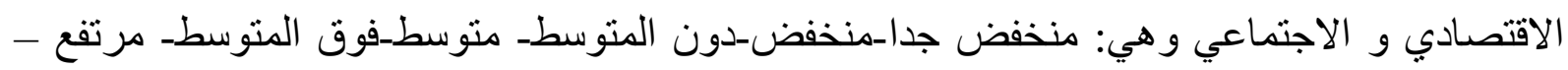
مرتفع جدا.و هذا يتيح فرصة أوسع لإيجاد فروق بين المستويات الاقتصادية والاجتماعية المختلفة. r - هي تللك الدفاهيم المرتبطة بالقصة مثل مفهوم ( البخل ) الذي ورد بقصة ( الثعلب البخيل ) بالبرنامج التدريبي للو الدين . 
• وصف المقياس: يتكون المقياس من تسعة أسئلة يتم الإجابة عليها بالتكملة ويتكون المقياس من ثلاثة أبعاد: بعد الوظيفة أو المهنة للجنسين وتم تقسيمه إلى تسعة مستويات ، بعد مستوى التعليم للجنسين وتم تقسيمه إلى ثمانية مستويات وتم استخدامه فى الدراسة الحالية على الوالدين ذوات المؤهل العالي ، بعد متوسط دخل الفرد في الثهر وتم تقسيمه إلى سبعة مستويات

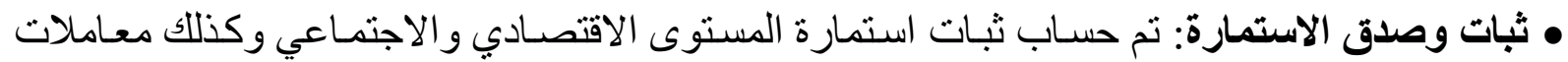

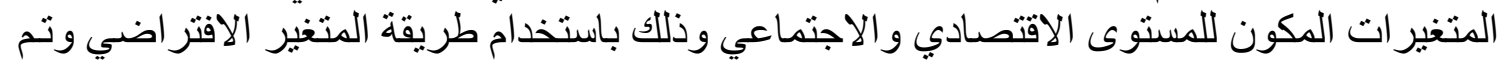

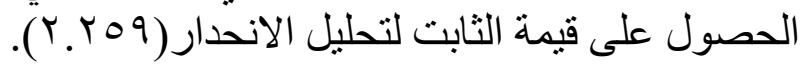
الأداه الثانية: اختبار مفاهيم طفل الروضة المصور للوابت الداين الهلف من الاختبار: قياس قدرة أطفال الروضة للمستوي الثاني (0_آ) سنوات من خلال تطبيق الو الدين اختبار المفاهيم (الرياضية ـ اللغوية_الفنية_ القصصية) على طفل الروضة. مصادر إعداد الاختبار: قامت الباحثة بالاطلاع على العديد من المقاييس والاختبارات التي تقيس الدفاهيم لاى طفل الروضة ، منها: اختبار الدفاهيم البيولوجية المصور إعداد/فاطمة عبدالرؤوف هانثم

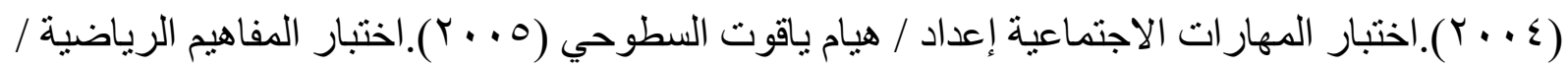

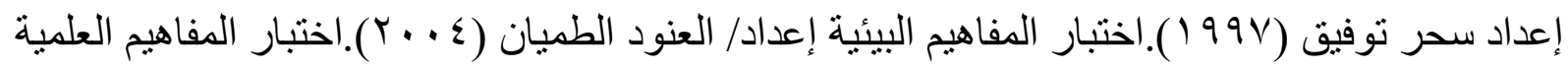

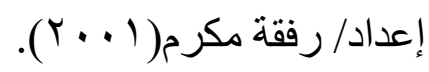

وصف الاختبار:

1- المفاهيم الرياضية :مفهوم العدد، دفهوم الأشكال الهندسية :، مفهوم البيع و الثراء : مفردات وتقيم كل مفردة بدرجة ،مفهوم الجمع و الطرح. r- المفاهيم اللغوية: مفهوم الحيوانات الأليفة :. مفهوم الفو اكه ،مفهوم الخضروات ، مفهوم حيوانات المزر عة - مان ץ- المفاهيم القنية: مفهوم الألوان :. مفهوم القص و اللصق ـ مفهوم الرسم

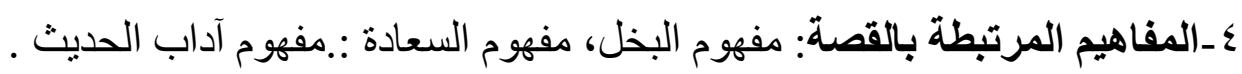
الكفاءة السيكومترية للاختبار: قامت الباحثة بالتأكد من الكفاءة السيكومترية للاختبار على عينة التقنين

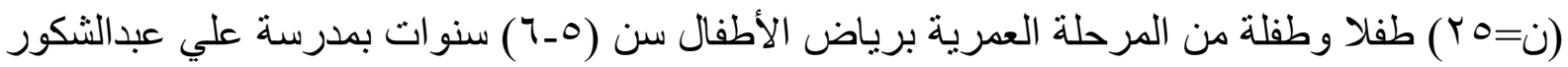
التجرييية للغات برياض الأطفال بمدينة كفر الثيخ "من غير عينة البحث الأساسية". 
['] الصدق: وقد قامت الباحثة بحساب الصدق عن طريق: أـ صدق المحك الخارجي: تعتمد نلك الطريقة على مقارنة درجات الاختبار بدرجات اختبار آخر تم استخدامه كمحك خارجي، حيث استخدمت الباحثة درجات التحصيل الدراسي كمحك، وقد حصلت الباحثة على معامل ارتباط قيمته 99. ب- صدق المحكمين: تم عرض الاختبار في صورته الأولية على (•(1) من السادة المحكمين المتخصصين في مجال رياض الأطفال بالجامعات، حيث طلبت الباحثة منهم إبداء الرأي حول ما يلي:مدى ملاءمة كل سؤال للمفهوم المنتمي إليه.مدى مناسبة جميع الأسئلة ككل لطفل الروضة.مدى وضوح ودقه الصياغة في أسئلة الاختبار وصوره لطفل الروضة.مدى مناسبة عدد الأسئلة التي يتكون منها الاختبار لكل مفهوم رئيسى. وقد اتفق المحكمين على:مفردات الاختبار متسقة مع أهداف الدراسة. الاختبار بصورة كلية ملائم لعينة الدر اسة. المفردات المصورة في معظمها مناسبة للأطفال مع إجر اء بعض التعديلات البسيطة. تبسيط لغة السؤال في بعض الأسئلة لتلائم العدر الزمني والعقلي للأطفال. تم توضيح أن أسئلة الاختبار تقدم للطفل بصورة شفهية وبلغة عربية بسيطة لكل الأطفال. وتم الأخذ بآراء السادة المحكمين من حذف أو إضافة وتعديل ج - حساب زمن الاختبار :يحتاج إلي • ب دقيقة للإجابة على الاختبار وتم تطبيقه بصورة فردية . [Yץ] الثبات: وقد قامت الباحثة بحساب ثبات الاختبار من خلال معادلة ألفا كرونباخ: من خلال معادلة ألفا كرونباخ، حصلت الباحثة على النتائج التالية: جدول (ع ) معاملات الثبات لاختبار الو الدين بمعادلة ألفا كرونباخ

\begin{tabular}{|c|c|}
\hline معادلة ألفا كرونباخ. & المفاهيم \\
\hline$\cdot, V^{7}$ & المفاهيم الرياضية \\
\hline$\therefore, \wedge \varepsilon$ & المفاهيم اللغوية \\
\hline$\cdot, Y Y$ & المفاهيم الفنية \\
\hline., 79 & المفاهيم المرتبطة بالقصة \\
\hline$\cdot, v \leq$ & الدرجة الكلية \\
\hline
\end{tabular}

يتضح من الجدول السابق أن معاملات الثبات بمعادلة ألفا كرونباخ للارجة الكلية ع V, • دالة وهي تدل على ثبات الاختبار. و على ذلك تكون الباحثة قد تأكدت من صدق وثبات الاختبار مما يجعل استخدام الاختبار مناسباً وملائماً لتلك العينة. 
إجراءات تطبيق الاختبار: قامت الباحثة بتجريب الاختبار على عينة من أطفال الرياض المستوى الثانى(0_T) و عددهم 0 ط طفلا وطفلة وذلك بخلاف العينة الأصلية وذلك لحساب زمن الاختبار والتأكد من صدقه وثباته ، قام الو الدان بتطبيق الاختبار على طفل الروضة في المنزل قبل وبعد البرنامج التدريبي

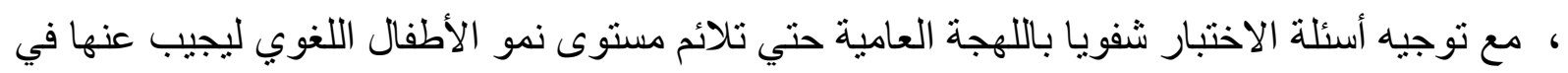
ضوء الصور المعروضة ، خصصت الباحثة لكل مفردة درجة في حالة الإجابة الصحيحة وصفر ا إذا

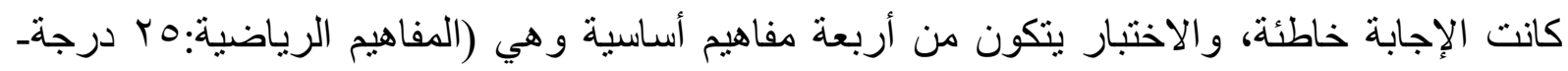

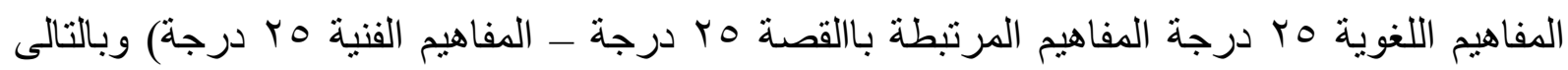

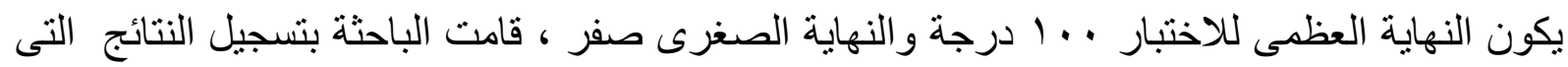

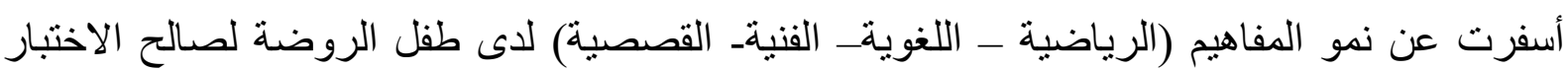

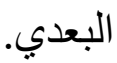

الأداه الثالثة: البرنامج التدريبى للوالدين لإنتاج بعض الألعاب التعليمية لدى طقل الروضة. الهـف الرئيسى من البرنامج التدريبى للوالدين: يهدف البرنامج التدريبى إلى تدريب الو الدين لإعداد

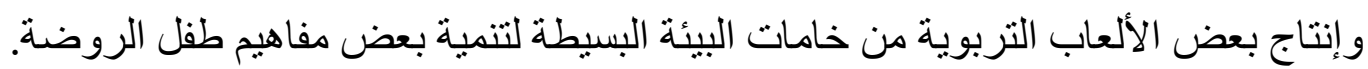
أولاً:- الأهداف العامة للبرنامج التدريبى للو الاين: ا ـ إدداد الو الدين بالجديد فى طرق وأساليب التعليم الفعال ، إعطاء الوالدين بكفاءة عالية فى إعداد و إنتاج الألعاب التربوية لأطفالهم.

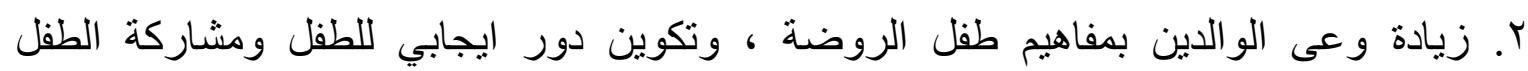
و الو الدين فى إعداد و إنتاج الألعاب التربوية المختلفة. r. مر اعاة خصائص النمو و الجو انب المختلفة لطفل ما قبل المدرسة. ع. يتعرف الو الدين على مدى أهمية المشاركة الفعالة مع معلمة الروضة.

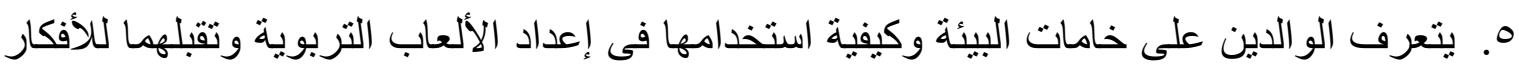
الجديدة واحتر امها. 7. تتمية مهار ات توليد الأفكار وتوظيف الخامات البيئية فى إعداد و إنتاج الألعاب التربوية لاى طفل

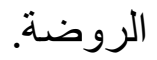

V. يتعرف الو الدان على احتياجات وميول ورغبات أطفالهم من الألعاب التربوية.

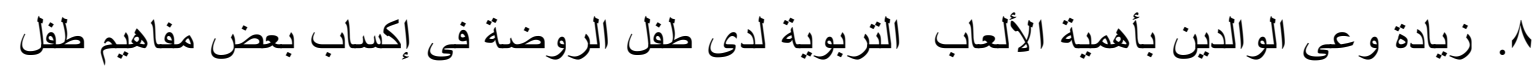

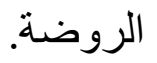




\section{ثانياً:- الأهداف الخاصة للبرنامج التدريبي للوالدين:}

ا ـ أن تلبى أهداف البرنامج حاجات الو الدين ، وتر اعى الفترة الزمنية المحددة للبرنامج التدريبى r. تدريب الوالدين على إعداد وإنتاج الألعاب التعليمية التى تخدم الجوانب(الرياضية، اللغوية ،

$$
\text { الفنية ، القصصية). }
$$

؟. . التركيز على جوانب الضعف الموجودة لدى الو الدين ، وتدرج خبرات الوالدين فى هذا المجال. ء. أن يتدرب الوالدان على كيفية جذب انتباه أطفالهما عن طريق المشاركة فى إعداد الألعاب

\section{التعليمية.}

•. التكامل بين الألعاب التربوية والأنشطة المختلفة للبرنامج التدريبى (الرياضية، اللغوية ، الفنية ،

\section{القصصية ).}

ثالثاً:- المدة الزمنية لتطبيق البرنامج التدريبى للوالدين: استغرق تطبيق البرنامج التدريبى مدة شهرين ( ^ أسابيع) بواقع "مرتان" فى الأسبوع.لمدة "ساعتين" فى الجلسة التدريبية الواحدة ، حيث أن عدد جلسات البرنامج (T (1) جلسة تدريبية فبالتالي يكون إجمالي عدد ساعات البرنامج (Yr) ساعة، رابعاً:- عدد المشتركين فى البرنامج التدريبى للوالدين:( • ع)أب و أم وتم تقسيمهما إلى مجمو عتين:

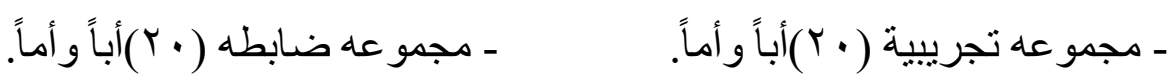

خامساً:- محتوى البرنامج التدريبى للوالدين: صمح محتوى البرنامج التدريبى الذى أعدته الباحثة لتدريب الو الدين على أربعة وحدات أساسية وهى:الوحدة الأولى: ألعاب تعليمية لتنمية المفاهيم الرياضية ، الوحدة الثانية: ألعاب تعليمية لتنمية المفاهيم اللغوية، الوحدة الثالثة: ألعاب تعليمية لتنمية النشاط الفني ،الوحدة الر ابعة: ألعاب تعليمية لتنمية النشاط القصصي. ووصفهم كالتالي: الوحدة الأولى " الألعاب التعليمية للمفاهيم الرياضية " الجلسة التدريبية الأولى(الأسبوع الأول): مفهوم العدد من ( ا - 1) .الجلسة التدريبية الثانية (الأسبوع الأول): مفهوم الأشكال الهندسية. الجلسة التدريبية الثالثة(الأسبوع الثانى): مفهوم البيع والثراء ـالجلسة التدريبية الرابعة(الأسبوع الثانى): مفهوم الجمع

الوحدة الثانية " الألعاب التعليمية للمفاهيم اللغوية "الجلسة التدريية الأولى (الأسبوع الثالث):مفهوم الحيوانات الأليفة والمفترسة ، الجلسة التدريبية الثانية (الأسبوع الثالث): مفهوم الفواكه ، الجلسة التدريبية الثالثة (الأسبوع الرابع): مفهوم الخضروات ،الجلسة التدريبية الرابعة (الأسبوع الرابع):

$$
\text { مفهوم طيور المزر عة . }
$$


الوحدة الثالثة "الألعاب التعليمية للأنثطة الفنية "الجلسة التدريبية الأولى (الأسبوع الخامس): التشكيل الحر بالعجائن ، الجلسة التدريبية الثانية(الأسبوع الخامس): قشر البيض العجيب الجلسة التدريبية الثالثة (الأسبوع السادس): مقلمة مبتكرة ، الجلسة التدريبية: الر ابعة (الأسبوع السادس): سلة أوراق

الوحدة الرابعة " الألعاب التعليمية للأنشطة القصصية " الجلسة التدريبية الأولى (الأسبوع السابع): مسرح العر ائس ، الجلسة التدريبية الثانية (الأسبوع السابع): عمل شخصيات قصة "الثعلب البخيل" ، الجلسة التدريبية الثالثة (الأسبوع الثامن):عمل شخصيات قصة " زقزوق يحب الحق " ، الجلسة التدريبية الر ابعة(الأسبوع الثامن): عمل شخصيات قصة "الكتاكيت السحرية" . وقد احتوى البرنامج على مجموعة من الأدوات والخامات البيئية البسيطة الموجودة فى المنزل ، ومن أهم الأدوات و الخامات البيئية المستخدمة فى البرنامج التدريبى ما يلى: علب الكارتون الفارغةـ الملاعق البلاستيك ـ الفار غة ـ الورق بأنو اعهـ العجين ـ الأسلاك المطاو عة ـ قثر البيض...). مصـادر إعداد البرنامج:_استمدت الباحثة الأساس العلمي للبرنامج من الكتب العلمية التي اهتمت بالألعاب التربوية المختلفة ومنها :الألعاب التربوية ( ( . ب)، الفن العجيب باستخدام المهولات (V . . Y) ، التربية الفنية والأشغال اليدوية ( . . ب)، كراسة تطبيقات في التدريب الميداني لمعلمة الروضة، المناشط الفنية لطفل الرياض( ( . . . ). ومن البحوث و الدر اسات في مجال التربية والتي اهتمت خاصة بمرحلة الطفولة و استخدمت الألعاب التربوية كوسيلة لتحسين المهار ات و المفاهيم في مرحلة رياض الأطفال ومنها: دراسة

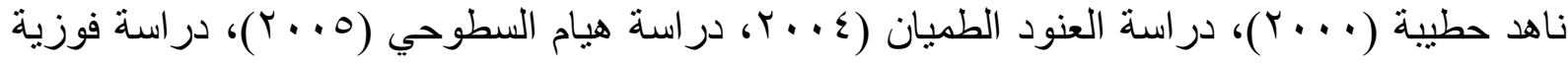
أحمد السويدي (9 . . ب).ومن مواقع الإنترنت ومنها:

http://www.mo3alem.com http://www.billybear4kids.com/clipart/clipart.htm http://www.syrianstory.com/lina.htm http://www.kidsdomain.com

تحكيم البرنامج:تم عرض البرنامج في صورته الأولية على (• ( ) من السادة المحكمين من المتخصصين في مجال رياض الأطفال بالجامعات وتم عمل التعديلات التي أقرها السادة الدحكمين على البرنامج بالحذف و الأضافة و التعديل. * الخطوات الإجرائية لتنفيذ البرنامج التّريبي للوالدين: بدأت الباحثة تطبيق البرنامج التدريبي بعد التجهيز القبلي للأدو ات ،واختيار عينة الدر اسة من الو الدين من خلال استمارة استطلاع رأي الو الدين 
ـ قامت الباحثة بعقد اجتماع أولي مع الو الدين قبل بداية البرنامج التدريبي وذللك بهدف التعارف عليهم

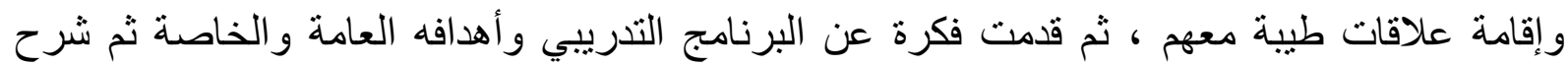
لمحتو اه، و الخامات والأدوات المستخدمة بالبرنامج لعمل الألعاب التربوية ، وقد لاحظت الباحثة ترحيب

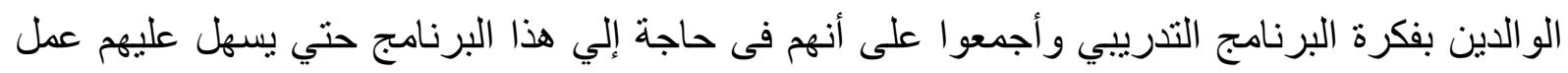

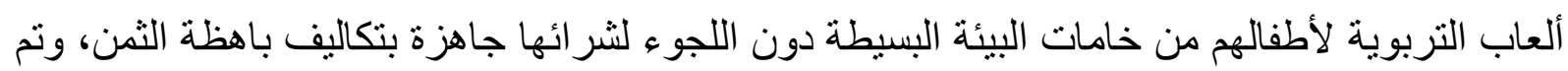
تحديد مو اعيد التطبيق مع الو الدين وبالتنسيق مع إدارة الروضة، وتم توزيع اختبار الدفاهيم المصور لطفل الروضة علي الو الدين لقيامهم بالتطبيق القبلي مع أطفالهم بالمنزل، وطلبت منهم الباحثة إحضار الاختبار معهم في الجلسة التدريبية الأولى من البرنامج التدريبي. ـ قامت الباحثة بتصوير الو الدين بالصور الفوتوغر افية أثناء تنفيذهم للعبة التربوية، وتم تصوير كل لعبة بعد الانتهاء من تتفيذها ، ثم بتقييم أداء الو الدين قبل وبعد الجلسة وذلك عن طريق تقديم بطاقات تقييم أداء الو الدين للألعاب التربوية. - في نهاية البرنامج التدريبي قامت الباحثة بتقديم دليل الو الدين كمرشد لهم في تنفيذ الألعاب التربوية لدى طفل الروضة وتم إلحاق اختبار تطبيق المفاهيم الدصور به .حتى يقوم الوالدان بتطبيق الاختبار على

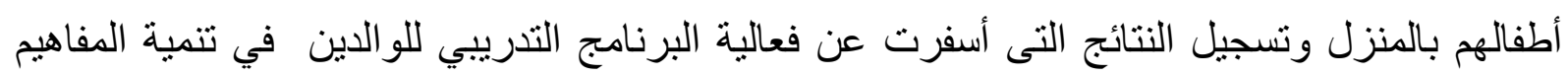
(الرياضية ـ اللغوية_ الفنية ـ القصصية) لدى طفل الروضة. *الأداه الرابعة :دليل الوالدين لإنتاج الألعاب التربوية في تنميـة بعض مفــاهيم طفل الروضـة نم تصميم

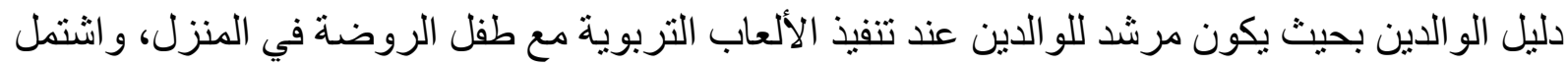
على مجموعة من الأهداف التعليمية ، خطوات تصميم اللعبة التربوية ، شروط اللعبة التربوية الجيدة ، أهمية المشاركة بينهم وبين معلمة الروضة ، ودور الوالدين في الدهين تفعيل اللعب وتتمينه في حياة الطفل ،و الألعاب التربوية التي يقوم بها الوالدان مع الطفل في المنزل ، وتتفق هذه الألعاب التربوية مع طبيعة

$$
\text { نتائج البحث: البرنامج المقدم للو الدين. }
$$

['] - نتائج الفرض الأول: ينص الفرض على أنه: " توجد فروق ذات دلالة إحصائية عند مستوي(0 •. ) بين متوسطي درجات المجموعة التجريبية من الوالدين ودرجات المجموعة الضابطة من الوالدين في القياس البعدي على مقياس مفاهيم طفل الروضة لصالح المجموعة دله

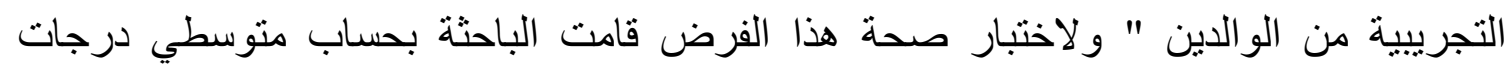
المجموعة التجريبية من الو الدين ودرجات المجموعة الضابطة من الوالدين في القياس البعدي ، وقد 
تم استخدام اختبار "ت" للتحقق من وجود فرق بين منوسطي درجات المجمو عتين ، ويتضح ذلك

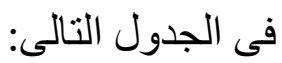

جدول (•) اتجاه الفروق بين متوسطي درجات القياس البعدى لدى أفراد المجمو عتين التجريبية ودرجات الضابطة لدي الو الدين على مقياس مفاهيم طفل الروضة .

\begin{tabular}{|c|c|c|c|c|c|c|c|c|}
\hline مستوى الدلاية & "قيمة & د.د & معياري & متوسط & $\dot{ن}$ & المجموعة & \multicolumn{2}{|l|}{ اختبار المفاهيم } \\
\hline \multirow{2}{*}{$\because 1$} & \multirow{2}{*}{$V .7 V T$} & \multirow{2}{*}{ rᄉ } & $1.0 \wedge 9 \leqslant$ & $1 V .$. & $r$. & التجريبية & \multirow{2}{*}{ المفاهيم الرياضية } & $\overline{1}$ \\
\hline & & & $1.0 \leqslant Y \leqslant$ & IT.r. & $r$. & الضـابطة & & \\
\hline \multirow{2}{*}{$\because 1$} & \multirow{2}{*}{$q . r r$} & \multirow{2}{*}{ rᄉ } & $1 . r \leqslant 17$ & IV.r. & $r$. & التجريبية & \multirow{2}{*}{ المفاهيم اللغوية } & 里: \\
\hline & & & $1.491 V$ & Ir.s. & $r$. & الضـابطة & & ज \\
\hline \multirow{2}{*}{$\because 1$} & \multirow{2}{*}{$9 . \wedge 9 \%$} & \multirow{2}{*}{ rᄉ } & $1 . V I Y$ & $1 V_{.1}$. & $r$. & التجريبية & \multirow{2}{*}{ المفاهيم الفنية } & \\
\hline & & & $1 . r v i v$ & Iro.. & $r$. & الضـابطة & & \\
\hline \multirow{2}{*}{$\because \cdot 1$} & \multirow{2}{*}{$9 . \wedge 9 \wedge$} & \multirow{2}{*}{ T人 } & 1.1704 & $1 V_{.1}$. & $r$. & التجريبية & \multirow{2}{*}{ 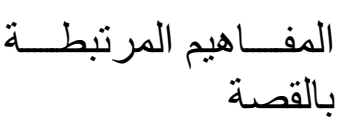 } & \\
\hline & & & Q 194. & IT.r. & $r$. & الضـابطة & & \\
\hline \multirow{2}{*}{$\because 1$} & \multirow{2}{*}{10.211} & \multirow{2}{*}{ rᄉ } & r... & 71.0. & $r$. & التجريبية & \multirow{2}{*}{ المجموع } & \\
\hline & & & וץז. & . . . . . & $r$. & الضـابطة & & \\
\hline
\end{tabular}

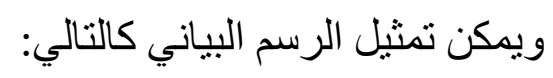

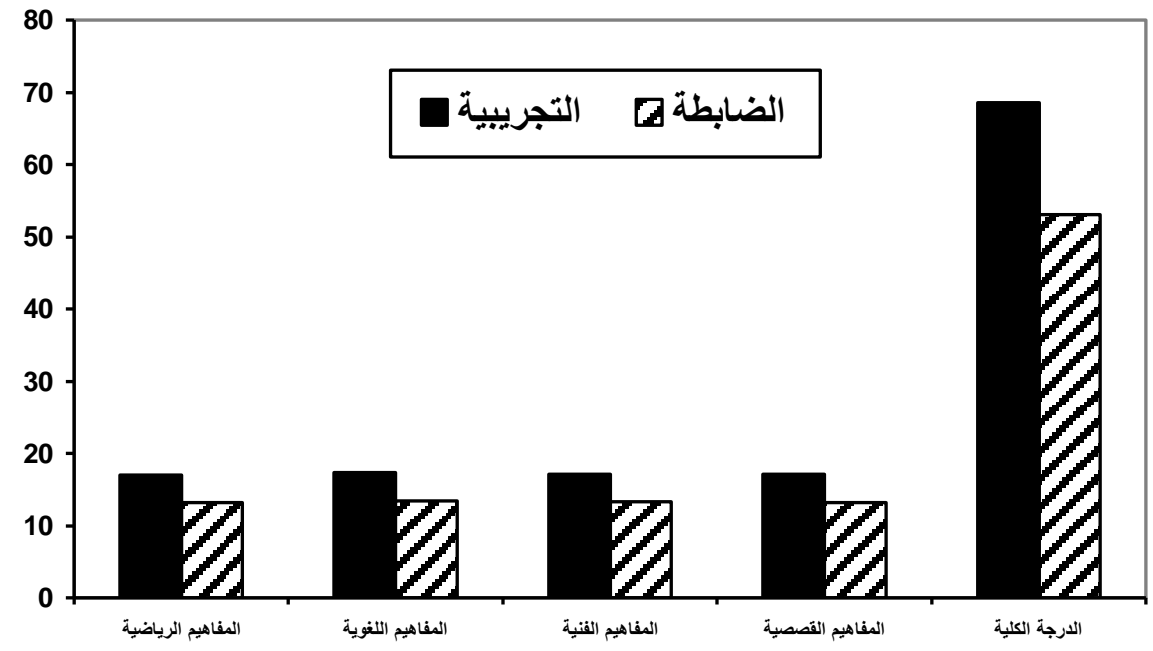

شكل (1) التمثيل البياني لمتوسطي درجات أفراد المجموعة التجريبية من الوالدين والضابطة في القياس البعدي على مقياس مفاهيم طفل الروضة لصالح التطبيق البعدي. 
ويتضح من جدول السابق ومن الرسم البياني شكل (1) وجود فروق داله إحصائيا بين منوسطي درجات المجموعتين المجموعة التجريبية من الوالدين ودرجات المجموعة الضابطة من الوالدين في القياس البعدى للمجموعة التجريية ، حيث كان الفرق دال عند مستوى ( • . •) على مقياس مفاهيم طفل

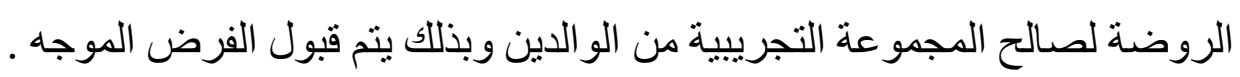

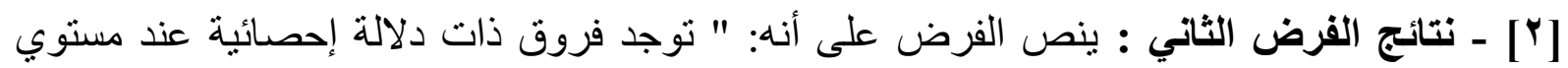

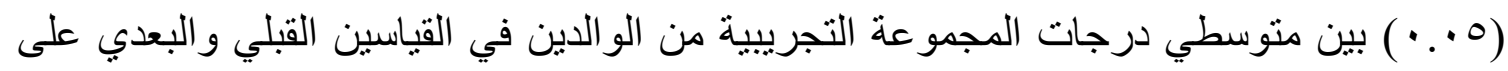
مقياس مفاهيم طفل الروضة لصالح القياس البعدي". و لاختبار صحة هذا الفرض قامت الباحثة

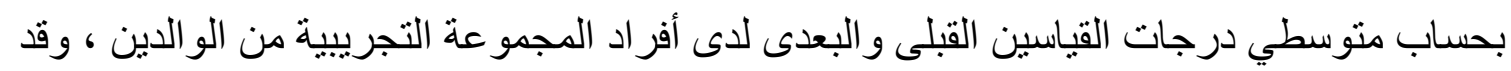

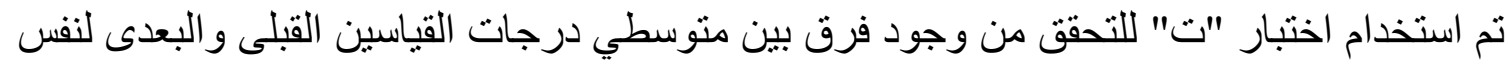

$$
\text { أفر اد المجمو عة ، ويتضح ذللك فى الجدول التالى: }
$$

جدول (؟) اتجاه الفروق بين منوسطي درجات القياسين القبلى و البعدى لدى أفر اد المجموعة التجريبية من

الو الدين على مقياس مفاهيم طفل الروضة

\begin{tabular}{|c|c|c|c|c|c|c|c|}
\hline مستوى الدلالة & "تيمة & د.د & انحراف معياري & متوسط & ن & | القياس & الأدوات \\
\hline \multirow{2}{*}{$\because \cdot 1$} & \multirow{2}{*}{$r+90$} & \multirow{2}{*}{19} & $1.1 \leqslant V 1$ & 7.0. & $r \cdot$ & ق قبلي & \multirow{2}{*}{ المفاهيم الرياضية } \\
\hline & & & $1.019 \varepsilon$ & IV... & $r$. & بعدي & \\
\hline \multirow{2}{*}{$\because \cdot 1$} & \multirow{2}{*}{$r \leqslant .09$} & \multirow{2}{*}{19} & $1 . \Gamma \leq 10$ & $7.10 \ldots$ & $r \cdot$ & قبلي & \multirow{2}{*}{ المفاهيم اللغوية } \\
\hline & & & $1 . \Gamma \leq 17$ & IV.r. & $r$. & بعدي & \\
\hline \multirow{2}{*}{$\because \cdot 1$} & \multirow{2}{*}{ r^. ${ }^{\prime \prime}$} & \multirow{2}{*}{19} & $1 . r 4 \cdot V$ & 7.V. & $r \cdot$ & قبلي & \multirow{2}{*}{ المفاهيم الفنية } \\
\hline & & & 1.014 & $1 v .1$. & $r$. & بعدي & \\
\hline \multirow{2}{*}{$\because \cdot 1$} & \multirow{2}{*}{ Y૫. \&A } & \multirow{2}{*}{19} & $1 . r \pi \leq \varepsilon$ & $v .0 \ldots$ & $r \cdot$ & قبلي & \multirow{2}{*}{ لمفاهيم المرنبطة } \\
\hline & & & 1.1704 & $\mid v .1$. & $r$. & | بعدي | & \\
\hline \multirow{2}{*}{$\because \cdot 1$} & \multirow{2}{*}{$07.7 \mathrm{~V}$} & \multirow{2}{*}{19} & 1. rquV & rV.l. & $r \cdot$ & قبلي & \multirow{2}{*}{ المجموع } \\
\hline & & & r... & $7 \wedge .0$ & $r \cdot$ & بعدي & \\
\hline
\end{tabular}

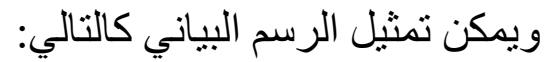




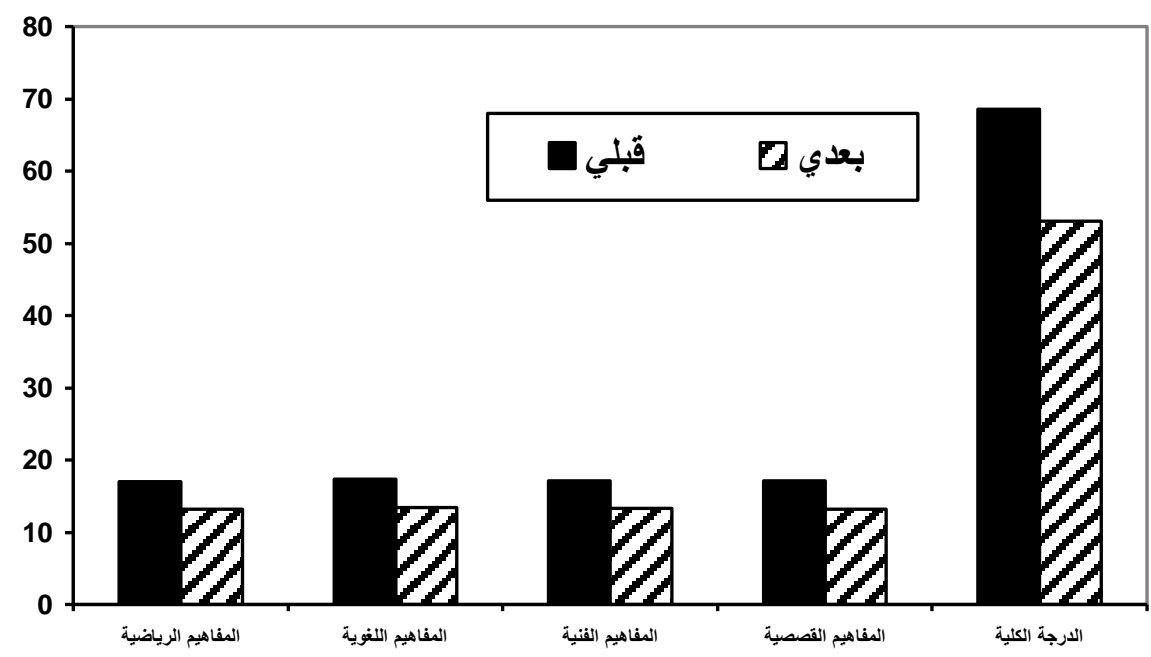

شكل (Y) التمثيل البياني لمتوسطي درجات أفر اد المجموعة التجرييية من الو الدين في القياسين (القبلي - البعدي) على مقياس مفاهيم طفل الروضة لصالح التطبيق البعدي . ويتضح من جدول السابق ومن الرسم البياني شكل (Y) وجود فروق داله إحصائبا بين منوسطي درجات القياسين القبلي والبعدى لدى أفراد المجموعة التجريبية من الوالدين ، حيث كان الفرق دال عند مستوى

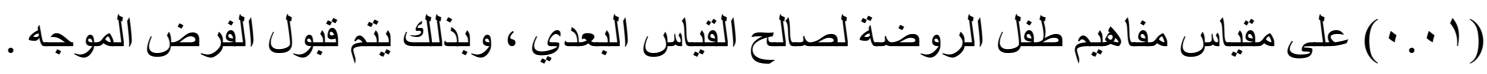

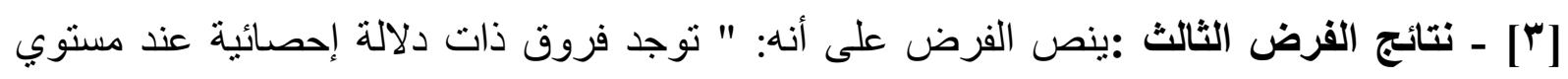

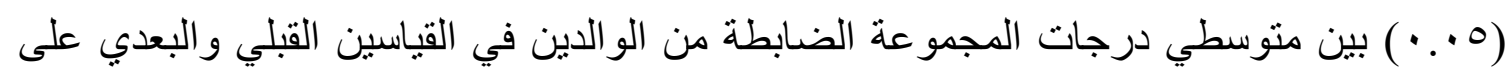

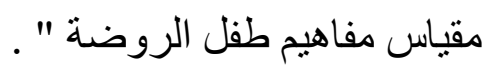

و لاختبار صحة هذا الفرض قامت الباحثة بحساب متوسطي درجات القباسين القبلى والبعدى لدى

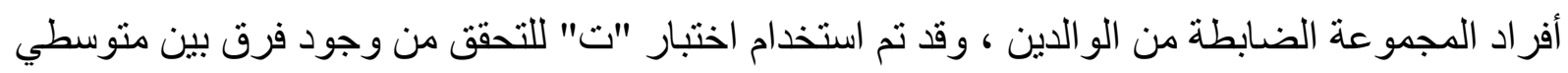
درجات القياسين القبلى و البعدى لنفس أفر اد المجمو عة ، ويتضح ذللك فى الجدول التالى: 
جدول (V) اتجاه الفرق بين متوسطي درجات القياسين القبلى والبعدى لدى أفراد المجموعة الضابطة من الو الدين على مقياس مفاهيم طفل الروضة .

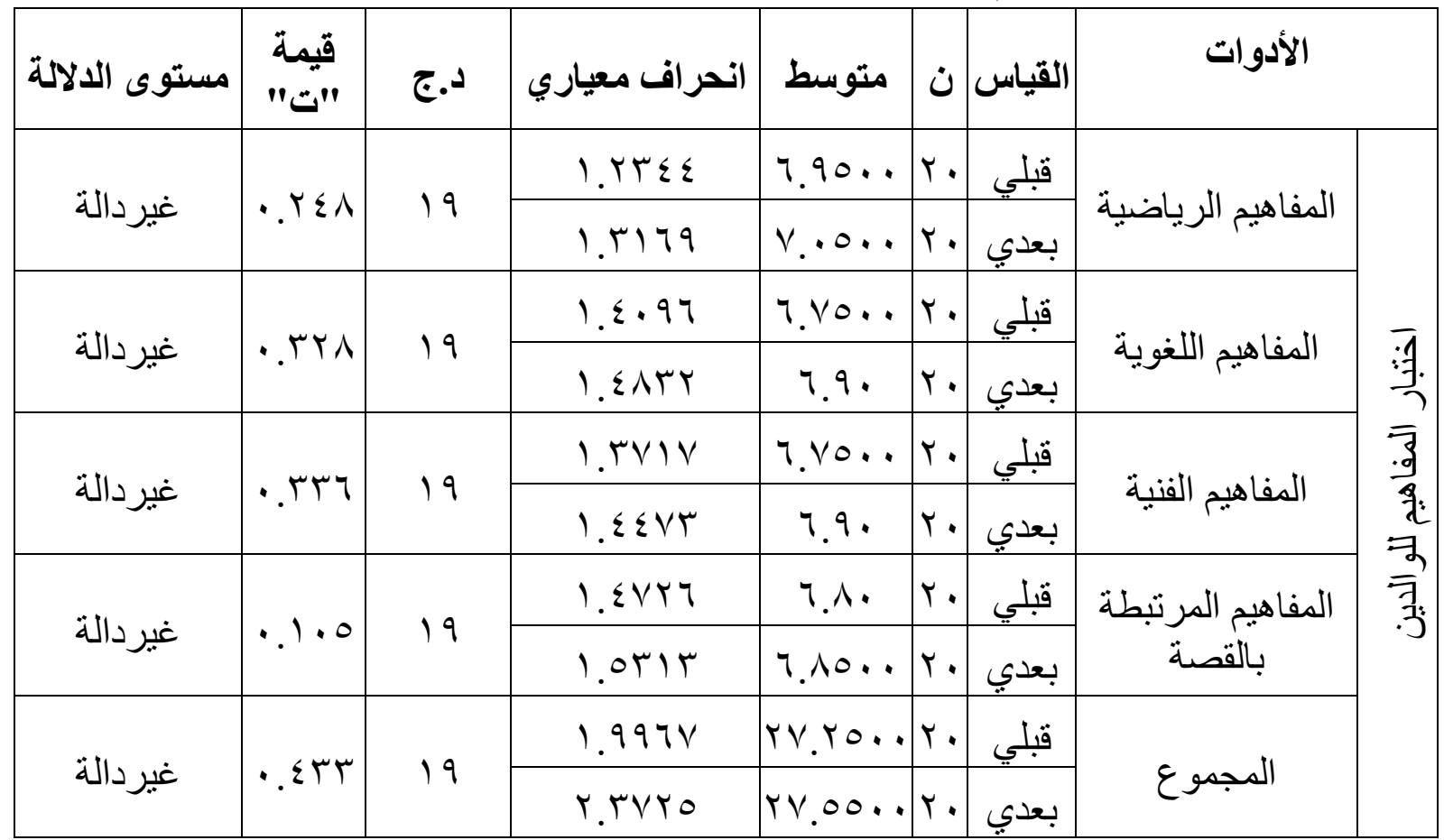

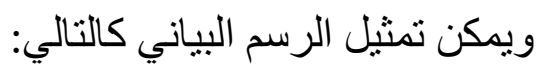

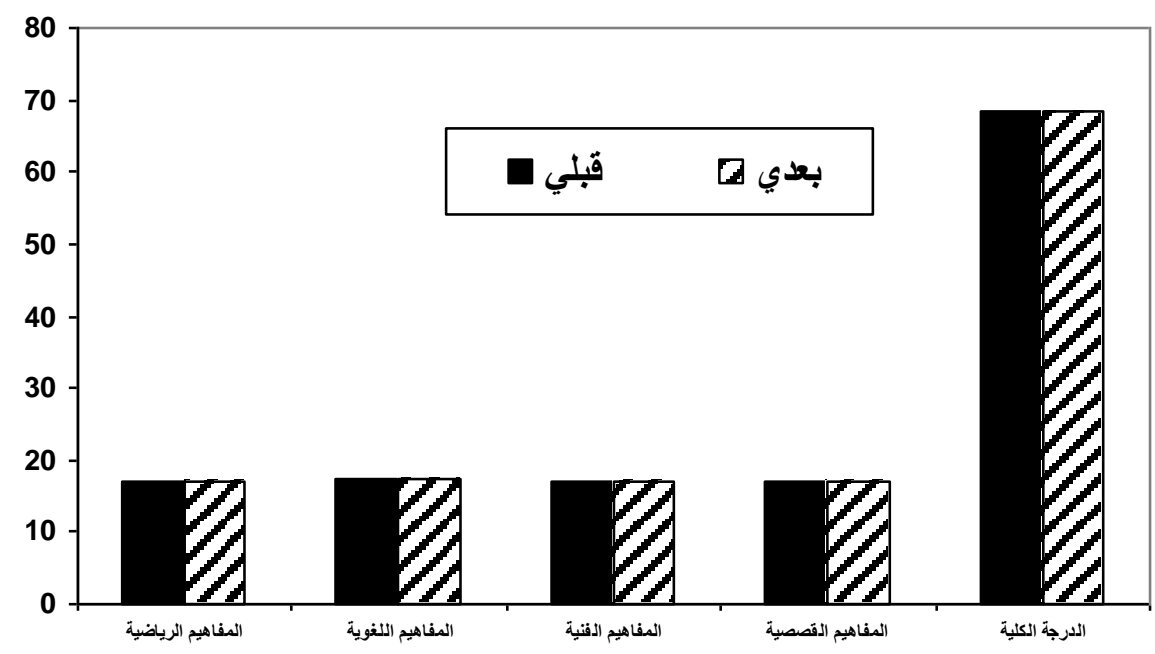

شكل (ب) التمثيل البياني لمتوسطي درجات أفر اد مجموعة الضابطة من الوالدين في القياسين (القبلي ـ البعدي) على مقياس مفاهيم طفل الروضة لصالح التطبيق البعدي . 
ويتضح من جدول السابق والرسم البياني شكل (T) عدم وجود فرق دال إحصائيا بين متوسطي درجات القياسين القبلي والبعدى لدى أفراد الدجموعة الضابطة من الوالدين، حيث كان الفرق غير دال على مقياس مفاهيم طفل الروضة، وبذلك يتم قبول الفرض الصفري. ـ ملخص النتائج: يتضح مما سبق: م وجود فروق داله إحصائيا بين متوسطي درجات الدجموعتين المجموعة التجرييية من الوالدين ودرجات المجموعة الضابطة من الو الدين في القياس البعدى ، حيث كانت الفروق داله عند مستوى ( ( . •) على مقياس مفاهيم طفل الروضة لصالح المجموعة التجريبية من الوالدين ، وبذلك يتم

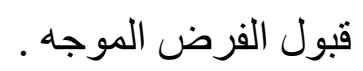
وجود فروق داله إحصائيا بين متوسطي درجات القياسين القبلي والبعدى لدى أفراد المجموعة التجريبية من الو الدين ، حيث كانت الفروق داله عند مستوى (1 •. •) على مقياس مفاهيم طفل

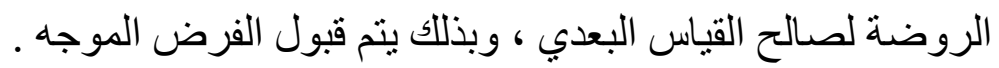

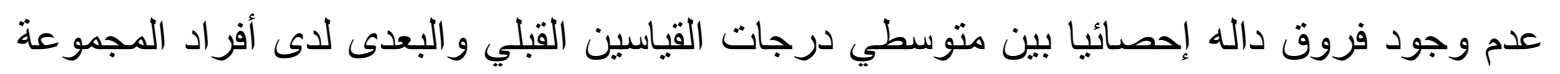

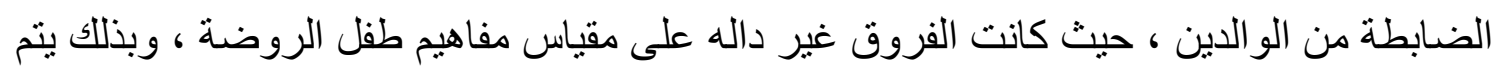
توصيات البحث: • ضرورة تشجيع الو الدين على مشاركة معلمات الروضة في الارتقاء بشخصية الطفل.

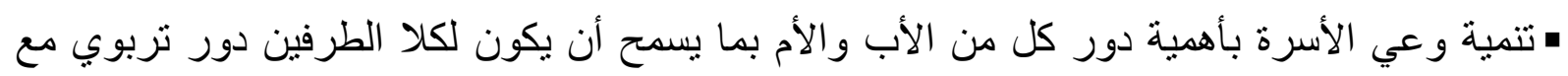

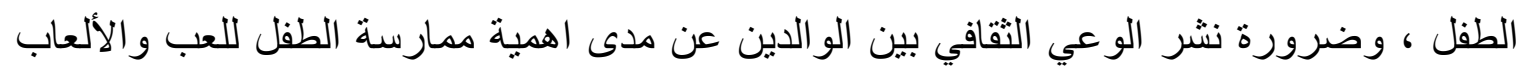
التعليمية في تنمية مفاهيم طفل الروضة. • أن يقضي الو الدان بعض الوقت مع الطفل و هو يلعب وننمى فيه الثقه بنفسه.

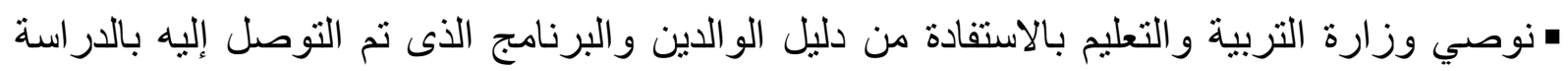
الحالية لانتاج وتصنيع الألعاب التعليمية لتنمية مفاهيم طفل الروضة.

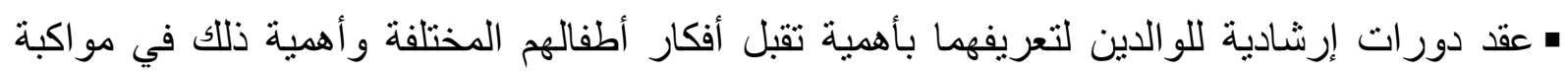
تحديات العصر الذي نعيش فيه. 


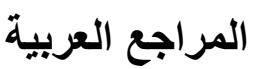

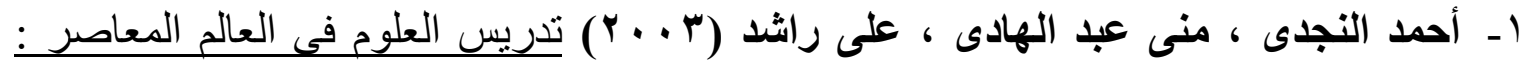

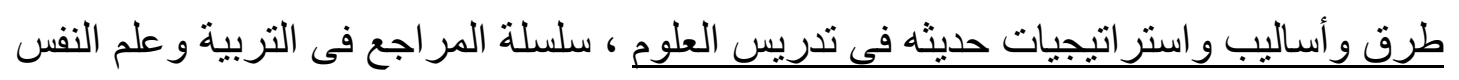
، المجلد V ب القاهرة ، دار الفكر العربى.

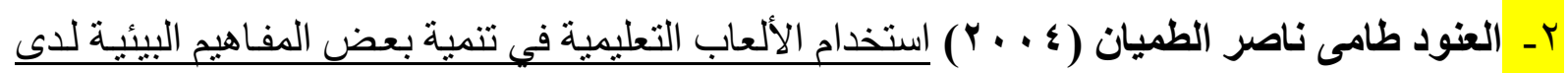

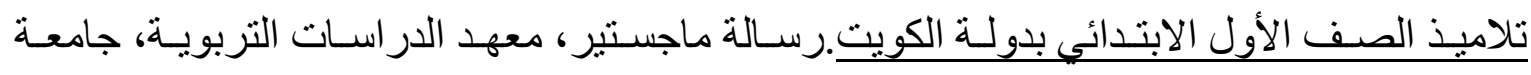
القاهرة.

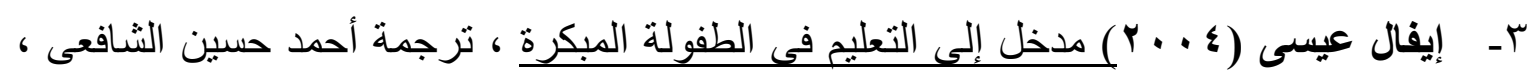
مر اجعة رشدى فام منصور، غزه - فلسطين ، دار الكتاب الجامعى. ـ- جبريل كالفى (1991 ) سيكولوجية طفل الروضية ، ترجمه طارق الأشر اف، مر اجعة وتقديم كاميليا عبد الفتاح، القاهرة ، دار الفكر العربى.

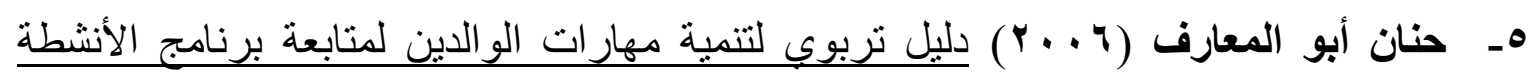
المتكاملة في رياض الأطفال، رسالة ماجستير ، كلية رياض الأطفال ، جامعة القاهرة.

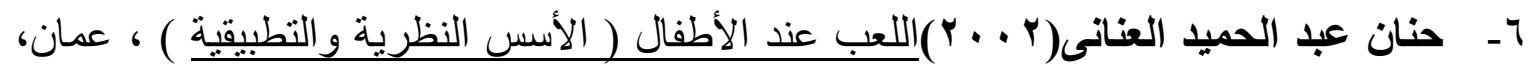
دار الفكر العربى.

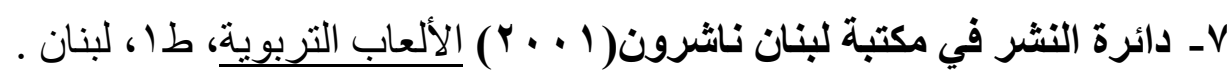

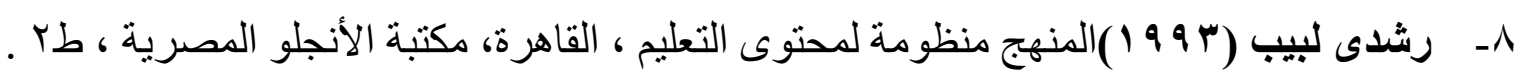

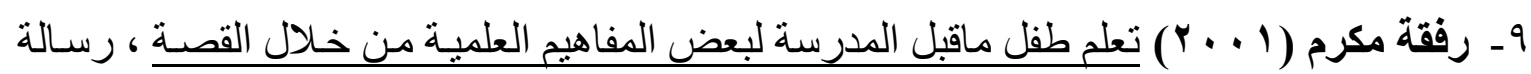

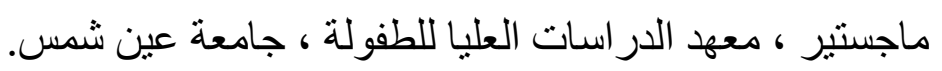

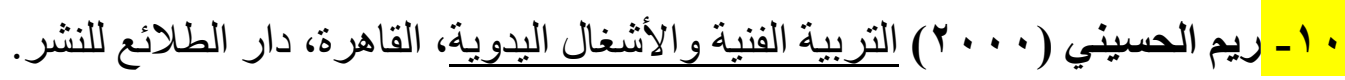

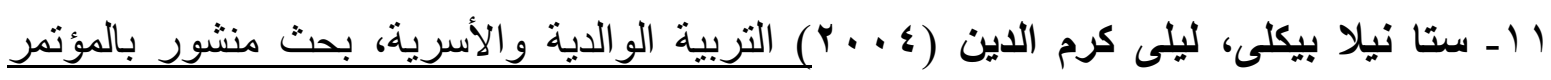
الإقليمي حول تطوير السياسات و الممارسات لر لرعاية وتربيه الطفولة المبكرة في الدول العربية،

$$
\text { القاهرة، مكتب اليونسكو الإقليمي و اللجنة الوطنية المصرية لليونسكو. }
$$

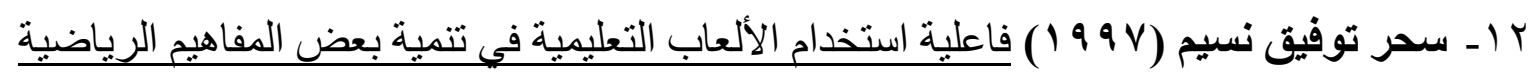

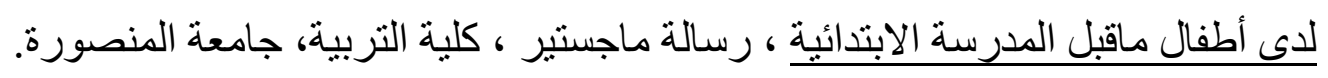

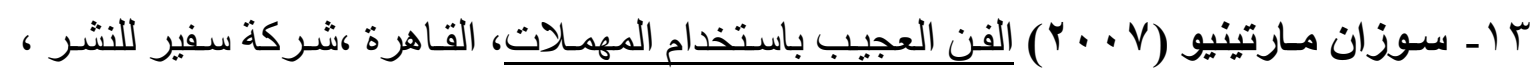
المهندسين. 
ع ا ـ سوسن إبراهيم التركيت (ץ . . ץ) الأطفال و اللعب،الإمارات العربية المتحدة، مكتبة الفلاح للنشر و التوزيع .

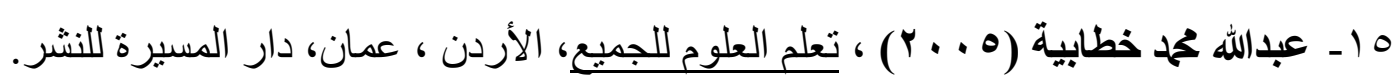
T ا ـ عزيزة اليتيم (ه . . Y) الأسلوب الابداعى في تعليم طفل ما قبل المدرسة أسسه ومهار اته ومجالاته، الكويت، مكتبة الفلاح.

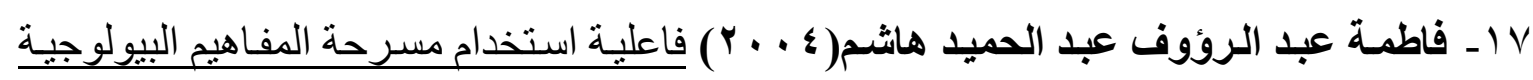
كطريقة لتحقيق بعض أهداف العلوم بالروضية ، رسـالة دكتور اه ، كلية ريـاض الأطفال ، جامعـة

القاهرة.

1 ـ فوزية أحمد عبيد السويدي (9 . . ب) التكامل بين الو الدين وريـاض الأطفال لمو اجهة بعض المشكلات التربوية لطفل ماقبل المدرسـة في دولة الأمـار ات العربية المتحدة ، رسـالة دكتور اه ، كلية رياض الأطفال ، جامعة القاهرة .

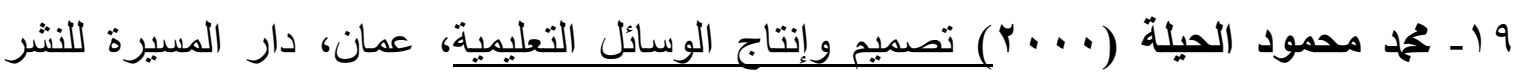
و التوزيع للطباعة.

• بـ ناهد فهمى على حطيبة كر اسة تطبيقات في التدريب الميداني ـمعلمـة الروضــة ، كليـة ريـاض الأطفال ،جامعة القاهرة.

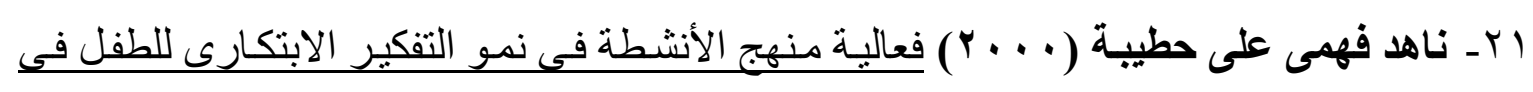
مرحلة رياض الأطفال ، رسالة دكتور اة، معهد الدر اسات التربوية ، جامعة القاهرة.

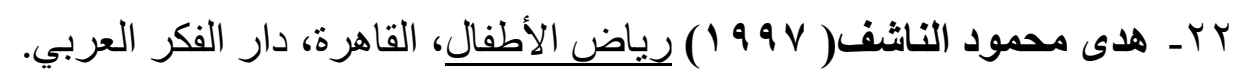
rr- هند بنت ماجد عحم ( . . . . إدارة رياض الأطفال ، الأمارات العربية المتحدة ،دار الكتاب الجامعى.

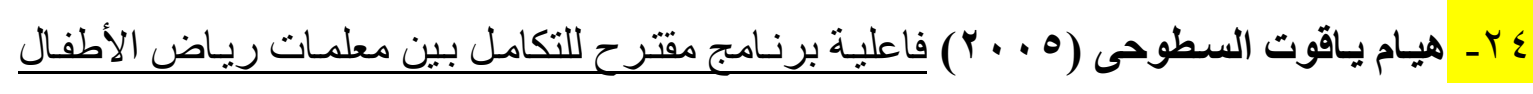
و الأسرة في تنمية بعض المهار ات الاجتماعية لطفل الروضـة، رسـالة ماجستير، معهد الدراسـات

$$
\text { و البحوث التربوية ، جامعة القاهرة. }
$$

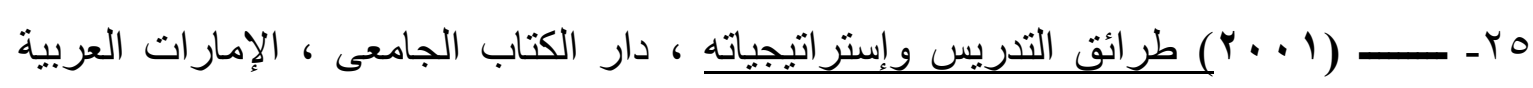
المتحدة

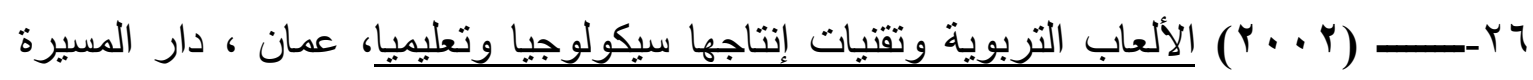
للنشر و التوزيع للطباعة. 


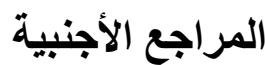

1- Sis or, D. (2001): Professional development workshop. Online: www/Professional development workshop/him.

2- Farrenkopf, Crol, and others( 1995): Social skills Development for Preschool Children with Visual Impairments, Paper Presented at the Annual International Convention of the Council for Exceptioual Children (37rd, Indianapolis, In April 5-9, PG.32.

3- Kenneth Rubin - Mills Rose Mary (1990) : Maternal Belisfs about Adaptive and Maladaptive Social Behaviors in Normal Aggressive and with DrownPrschool, Journal of Abnormal Child Psychology, Vol. 18, No 4, pg420.

4- Mantzicopoulos,-panayota- -y and ( 1993): Analysis of social and Personality Variables as Predictors of Preacademic Competence Among Disadvantaged Preschoolers, paper presented at the Biennial Meeting of The Society for research in Child Development, $60^{\text {th }}$, New Orleans, Ia, March 25-27, Indiana, pg. 46.

5- Morrison. S.,(1990) :Early Childhood Education TodayPublishing Co, columba,. 